\title{
Radon emanation and heavy-metals assessment of historical warm and cold springs in Nigeria using different matrices
}

\author{
E Babatope Faweya ${ }^{1 *}$, O Gabriel Olowomofe ${ }^{2}$, H Taiwo Akande $^{2}$ and T Adeniyi Adewumi ${ }^{3}$
}

\begin{abstract}
Background: In recent years, attention has been drawn to radon gas as main risk factor for lung cancer. Radon is colourless, odourless and tasteless radioactive noble gas. To mitigate radon effects, water consume by populace needs to be conserved. Radon concentration in water and heavy metals concentrations in sediment samples from historical cold and warm springs at Ikogosi were determined using Durridge RAD-7 analyzer with RAD $\mathrm{H}_{2} \mathrm{O}$ accessory and atomic absorption spectrophotometer.

Results: The mean activity concentration of radon in water samples ranged from 0.07 to 0.36 with overall mean value $0.20 \mathrm{~Bq} \mathrm{~L}{ }^{-1}, 35-210$ with an overall mean value $75.9 \mathrm{~Bq} \mathrm{~L}^{-1}$ and $11.7-140.0$ with an overall mean $79.4 \mathrm{~Bq} \mathrm{~L}^{-1}$ for bottled, cold and warm water samples respectively. The calculated total effective dose values were below $100 \mu \mathrm{S} v$ year $^{-1}$ recommended by WHO. The result of elemental analysis showed that the mean values of metals concentrations were $\mathrm{Pb}\left(2.9-11.8 \mathrm{mg} \mathrm{kg}^{-1}\right), \mathrm{Cu}\left(3.8-12.8 \mathrm{mg} \mathrm{kg}^{-1}\right)$, Fe $\left(945.0-2010.0 \mathrm{mg} \mathrm{kg}^{-1}\right), \mathrm{Cd}\left(0.6-1.7 \mathrm{mg} \mathrm{kg}^{-1}\right)$ and Ni $\left(0.3-2.6 \mathrm{mg} \mathrm{kg}^{-1}\right)$.

Conclusions: The results revealed values not higher than recommended permissible limit and background values. The pollution load index, revealed that the overall contamination of metals indicated no significant pollution in all the studied samples.
\end{abstract}

Keywords: Dose, Enrichment factor, Geoaccumulation index, Heavy-metals, Pollution index, Radon

\section{Background}

The three naturally occurring radon isotopes ${ }^{222} \mathrm{Rn}$, ${ }^{220} \mathrm{Rn}$ and ${ }^{219} \mathrm{Rn}$ are formed on the alpha decay of their radium parents ${ }^{226} \mathrm{Rn},{ }^{224} \mathrm{Rn}$ and ${ }^{223} \mathrm{Rn}$ respectively (IAEA 2013). The relevant physico-chemical properties such as half-lives, decay constants, average recoil energies on formation, diffusion coefficients in air $\left(D_{M A}\right)$ and diffusion coefficients in water $\left(D_{M W}\right)$ are (3.82 days, $2.10 \times 10^{-6} \mathrm{~s}^{-1}, 86 \mathrm{keV}, 1 \times 10^{-5} \mathrm{~m}^{2} \mathrm{~s}^{-1}, 1$ $\left.\mathrm{x} 10^{-9} \mathrm{~m}^{2} \mathrm{~s}^{-1}\right),\left(55.8 \mathrm{~s}, 1.2 \times 10^{-6} \mathrm{~s}^{-1}, 103 \mathrm{keV}\right)$ and $(3.98 \mathrm{~s}$, $1.74 \times 10^{-1} \mathrm{~s}^{-1}, 104 \mathrm{keV}$ ) for ${ }^{222} \mathrm{Rn},{ }^{220} \mathrm{Rn}$ and ${ }^{219} \mathrm{Rn}$ respectively (IAEA 2013). Radon half-life and solubility

\footnotetext{
*Correspondence: febdeprof@yahoo.co.uk;

faweya.ebenezer@lmu.edu.ng

${ }^{1}$ Radiation and Health Physics Division, Department of Physics, Faculty

of Science, Ekiti State University, P.M.B 5363, Ado-Ekiti, Nigeria

Full list of author information is available at the end of the article
}

have allowed the use of radon gas as a natural groundwater tracer to identify and quantify groundwater discharge to surface water (Skeppstrom and Olofsson 2007; Schubert et al. 2011; Ortega et al. 2015). The short-lived decay products of radon are responsible for most of the hazard by inhalation and ingestion. If radon and its daughters are ingested through water or inhaled in the air and decay inside the human lungs, the radiation has the potential to split water molecules and produce free radicals such $\mathrm{OH}$. The free radicals are very reactive and may damage the DNA of the cells in the lungs, thus causing cancer (Edsfeldt 2001). In addition, other organs, including the kidney and the bone marrow may receive certain amounts of doses if an individual drinks water in which radon was dissolved (Kendall and Smith 2002). Although the risk is very low when radon is in the open, in places such as caves, mines, volcanic soils, aluminous shale's, granite 
and rocky area such as Ikogosi, it can build up to dangerous concentrations. This may cause substantial health effect after long-term exposure (Crawford-Brown 1991; USEPA 1999; Yu and Kim 2004). Radon is extracted from the volcanic deposits in which the aquifer resides (Hector et al. 2015), its release taking place via emanation, transport and exhalation through the fissures network in the fracture system or from mantle degassing. Typical example of fissures through which radon could be released are Ikogosi warm and cold springs. The quantity of radon dissolved in groundwater discharge to surface water depends on different factors such as the characteristics of the aquifer, water-rock interaction (as seen in Ikogosi), water residence time within aquifer and material content of radium (Gundersen et al. 1992; Choubey and Ramola 1997; Choubey et al. 1997). Ninety-five percent (95\%) of exposure to radon is from indoor air; about one $(1 \%)$ is from drinking water sources (Kendall and Smith 2002). Most of this $1 \%$ drinking water exposure is from inhalation of radon gas released from running water activities such as bathing, showering, cleaning and healing as the people of Ikogosi believed in the healing potentials of the two springs. In many countries, some home obtain drinking water from ground sources (springs, wells, adits and boreholes) (Greeman and Rose 1996; Marazio-tis 1996; De Martino et al. 1998). Ikogosi warm and cold springs are not an exception in this aspect. The water was bottled for consumption by UAC and was named GOSSY WATER. Ikogosi Ekiti people still consume the spring water untreated because it is believed that the water has a lot of therapeutic properties to cure hypertension, guinea worm, hook worm, kidney stone, rheumatism, body rashes and pimples by either drinking it or bathing with it (Hairul et al. 2013). Apart from bottled water, tourists do visit the place for various purposes such as swimming, bathing, health reasons, aesthetic appreciation and pleasure. Underground water often moves out in two places (hot and cold) through fissures in the rock. The water might be contaminated by radon because of its volatility. Many countries in the world have defined an action level of radon concentration to guide their program to control domestic exposure to radon but this is not readily available in Nigeria. Among the vast different contaminants affecting water resources, heavy metals receive particular concern considering their strong toxicities even at low concentrations due to their cumulative effects (Momodu and Anyakora 2010). The temperature of the springs at the meeting point was attributed to the circulation of the normal groundwater to a depth of one to several thousand feet (Rogers et al. 1969). The circulation of groundwater has a potential filtering effect and possibility of water pollution through weathering of basement rocks. Chemical species such as $\mathrm{CO}_{3}{ }^{2-}, \mathrm{Ca}, \mathrm{Mg}, \mathrm{Na}, \mathrm{K}, \mathrm{Fe}$ which have some sanitary health effects as well as toxins such as $\mathrm{Pb}, \mathrm{Cd}, \mathrm{SO}_{4}{ }^{2-}$ could easily be introduced into the water through leaching (Oladipo et al. 2005). Toxic elements could be transferred to human through ground elements, surface water (Rasheed 2010) and sediment obtained from bottom of rivers, streams and springs (Faweya and Farai 2006; Faweya 2007; Faweya et al. 2013). Heavy metals are discharged into the river from numerous sources. They may be transported as either dissolved species in water or as an integral part of sediments (Shuanxi 2014). Sediments have been integral part of river basin with the variation of habitats and environments (Morillo et al. 2004). Sediments are not only the integral part of river basin but carrier of contaminants and potential secondary source of contaminants in aquatic systems (Calmano et al. 1990). Sediments have been widely reported as environmental indicator for the assessment of metal pollution in natural water (Islam et al. 2015). Liao et al. reported poor quality of water along rivers Kaoping and Tungkang in many points due to sediments that act as both sinks and sources of heavy metals (Liao et al. 2006). Therefore, analysis of sediment is a useful method to assess regional environmental pollution (Lai et al. 2010). Consumption of water contaminated by heavy metals from sediments may results in spread of diseases and health challenges such as reduced mental and central nervous function, lower energy levels, damage to blood through accumulation of lead in the blood stream by ingestion of contaminated aquatic species, lungs, kidneys and other vital organs (Jarup 2003; Tukura et al. 2014). Ikogosi warm and cold springs being natural water are located in Ekiti West Local government of Ekiti State of Nigeria in a valley from surrounding hills. Both warm and cold springs in the area play important roles guaranteeing water supply for domestic, agricultural, tourists attraction and bottled GOSSY water for urban needs by UAC Nigeria. The interest of this study lies in the fact that (a) during the last two decades there has been increase in consumption of treated waters in Nigeria, (b) commercially bottled and sachet water has partially substituted the consumption of tap water from municipal supplies, (c) residents ingest untreated water from the springs (d) Ikogosi warm and cold springs are one of the most visited tourists centre in Nigeria. Therefore, the presents study was carried out to provide information on (i) level of radon ${ }^{222} \mathrm{Rn}$ concentration in both treated (bottled) and untreated (source) water consumed in urban and local areas (ii) radiological dose that could be accrued to infants, children and adults due to consumption of water (iii) health risks that could be accrued to the populace due to the presence of heavy metals and other contents. The results obtained would be compared with recommended values by UNSCEAR, WHO and USEPA drinking standards. 


\section{Location of study area}

The two springs sprout out and flow with a constant temperature and volume up to $150 \mathrm{~L} \mathrm{~s}^{-1}$ from morning till night, at all seasons, all-year round (Kukoyi et al. 2013). The warm spring has a temperature of $70{ }^{\circ} \mathrm{C}$ at source and $36-37^{\circ} \mathrm{C}$ after meeting the cold spring (Kukoyi et al. 2013; Oladipo et al. 2005). Ikogosi is a town in Ekiti West Local Government Area of Ekiti State. The warm spring lies on longitude $5^{\circ} 0^{\prime} 0^{\prime \prime}$ East and latitude $7^{\circ} 40^{\prime} 0^{\prime \prime}$ North
(Fig. 1 Schematic map of the study area). This was done using Arc Gis 10. The topographical elevation varies from less than $473 \mathrm{~m}$ in the valleys to $549 \mathrm{~m}$ on the hills (Ojo et al. 2011).

\section{Materials and methods}

\section{Sampling procedure}

Twenty water samples were collected in various points along the springs and five samples of GOSSY

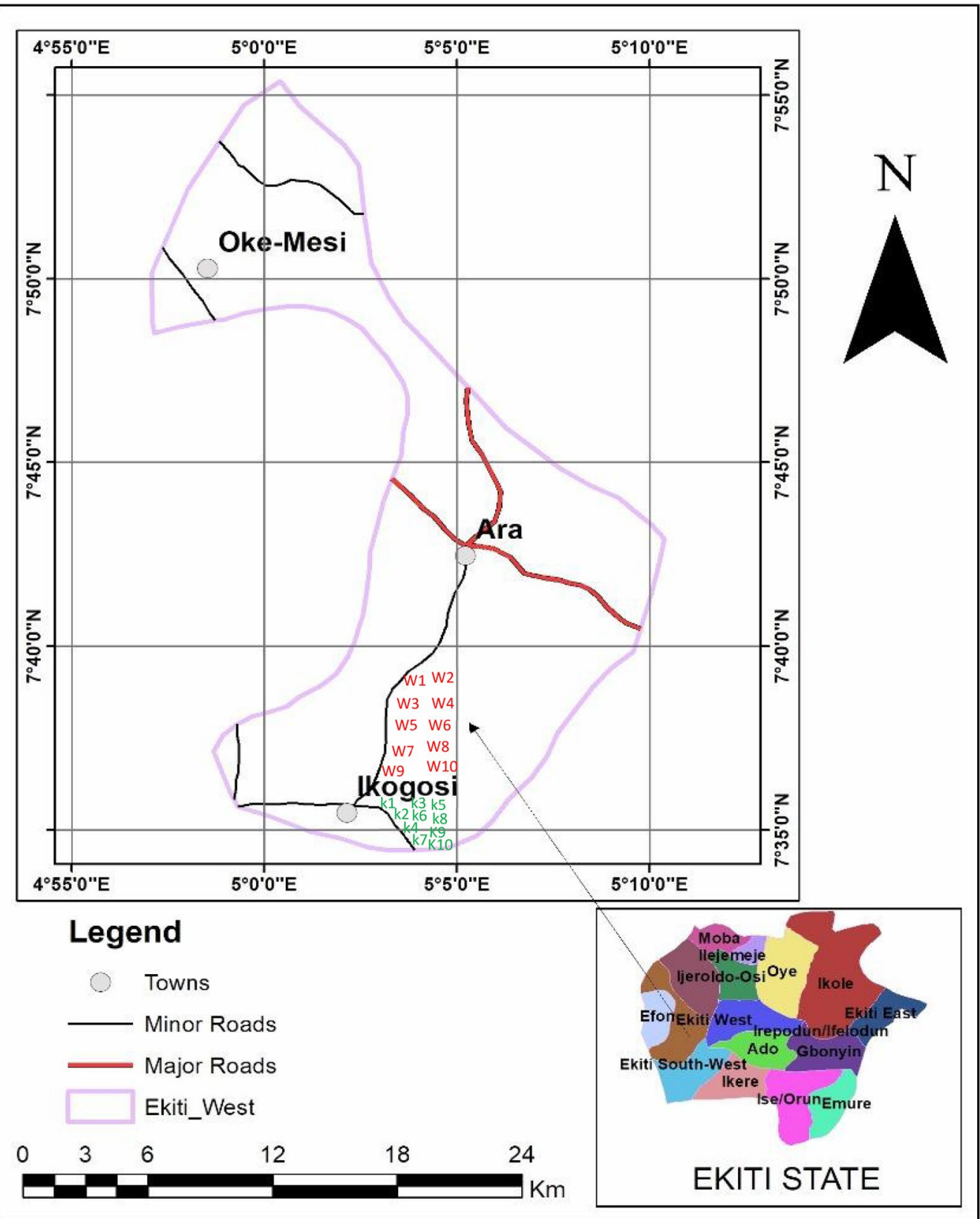

Fig. 1 Schematic map of the study area 
bottled water. Ten water samples were collected along each spring. At each point, $250 \mathrm{~mL}$ vials designed for radon-in-water activity measurement were filled to the edge with the sampled water and then closed immediately (Stringer and Burnett 2004). Conscious effort was made to prevent bubbling of water, in order not allow escape of dissolved radon by degassing during collection and transportation to the laboratory (Oni et al. 2014, 2016). Samples were taken to the laboratory immediately. Radon levels were determined within 3-6 h after sample collection in order to minimize the effect of radioactive decay (Hector et al. 2015). This project was carried out between January and August 2017. Sediment samples were collected at the bottom of the point where water samples were taken in order to have a better representation. Samples were collected with plastic-made tools to avoid metallic contamination. This was done in triplicate at each sampling point. Samples were kept in polythene bags that are free from heavy metal and organic impurities (Faweya et al. 2013; Pravin et al. 2014). In the laboratory triplicate samples from each point were thoroughly mixed to give gross samples. The sediment samples were air-dried and sieved using mesh $0.5 \mathrm{~mm}$ for uniform particle size. The samples were also oven-dried at a temperature of $105{ }^{\circ} \mathrm{C}$ (Alan et al. 1997) until constant weights were obtained.

\section{Laboratory measurements Analysis of radon}

Radon concentration in water samples was measured using an advanced radon-in-air RAD-7 radon analyzer (Durridge Co., USA) that uses alpha spectrometry technique (El-Taher 2012; Oni et al. 2014). The RAD7 radon detector was calibrated at the Durridge radon calibration facility at Billerica Massachusetts, United States. The calibration system was compared to a precision of better than $1 \%$, with a secondary standard chamber, which was in turn calibrated by comparison with a National Institute of Standards and Technology (NIST) radon standard supplied through the U.S. Environmental Protection Agency. The calibration system's accuracy was also check by making a direct measurement of radon level from activity and emission of a European standard radon source. The calibration achieves a reproducibility of better than $\pm 2 \%$ and an overall calibration accuracy of better than $\pm 5 \%$. The $\operatorname{Rad}-7$ used was maintained at between 6 and 10\% relative humidity for its efficiency not to decrease due to neutralization of ${ }^{218}$ Po ions by water particle (Ravikumar and Somashekar 2014). In the setup, 250-mL sample bottle was connected to RAD-7 detector via bubbling kit which enables it to degas radon from a water sample in into the air in a closed loop (Oni et al. 2014). To achieve this, the equipment was set to wat-250 for $5 \mathrm{~min}$. The equipment was allowed to rest for $5 \mathrm{~min}$ and then count each sample for $30 \mathrm{~min}$ in five cycles. Radon concentration was determined by RAD7 taking into consideration the calibration of RAD7, volume of the closed air loop of the set up and the size of the vial used. The counting time was shorter than 3.8 days the half-life of radon. This made RAD-7 better than other detectors for ${ }^{222} \mathrm{Rn}$ measurement in water. Five runs were done for each sample. At the end of the runs (after the start), the RAD-7 prints out automatically the summary, showing the average radon reading for the five cycles counted. The readings and typical alpha energy spectrum obtained from the capture software were shown in Figs. 5 and 6 of the Additional file 1 . The samples were counted immediately after collection without any delay, therefore radon decay correction was not calculated (Ravikumar and Somashekar 2014; Hector et al. 2015).

\section{Physico-chemical parameters study}

The sediment samples were analyzed for $\mathrm{pH}$, electrical conductivity, organic matter content, nitrogen and the heavy metal contents. The $\mathrm{pH}$ of the samples was determined using Jenway $3510 \mathrm{pH}$ meter. The sediment samples were mixed in a ratio of $1: 1$ with distilled water in a beaker before inserting the probes. Readings were taken after the instrument had stabilized. Conductivity was taken by dipping the conductivity probe into a mixture 1:1 of the sediment samples using Jenway 4520 conductivity meter. Organic matter (OM) was determined by wet combustion method (APHA 1995). One (1) g of each sample was weighed into a Pyrex beaker and $20 \mathrm{~mL}$ of con $\mathrm{HNO}_{3}$ was added to it. This was allowed to soak for $30 \mathrm{~min}$ and then transferred to a hot plate and heated at $400{ }^{\circ} \mathrm{C}$ until frothing stops and $\mathrm{HNO}_{3}$ was almost evaporated. Five (5) $\mathrm{mL}$ of conc $\mathrm{HClO}_{4}$ was added and watch glass placed of the beaker until sample became light strain in colour. The beaker was removed and allowed to cool, then the watch glass rinsed into the beaker with distilled water and the digest filtered into a $100 \mathrm{ml}$ volumetric flask. Heavy metal contents were determined by analyzing the prepared sediment filtrate using Atomic Absorption Spectrophotometer (BUCK 210 VGP). Others physical and chemical properties were determined using the standard techniques and methods (Hem 1985; APHA, AWWA, WEF 1998).

\section{Evaluation of doses in water and physico-chemical properties in the sediment Evaluation of mean annual effective dose}

Radon transports by water via ingestion and inhalation to the public is a very serious threat compared to other pollutants in water (Oni et al. 2016) because of dose accrued to the populace. Therefore, dose due to radon can be 
divided into two parts: ingestion (through consumption of water) and inhalation (when radon is released from water to indoor air) (Manzoor et al. 2008; Ravikumar and Somashekar 2014). The mean annual effective dose rate for ingestion and inhalation were calculated according to parameters introduced by UNSCEAR (2000) and were calculated as:

$$
\begin{aligned}
& E W I_{\text {ing }}\left(\mu \text { Sv year }{ }^{-1}\right)=C R_{n} W \cdot C W \cdot E D C \\
& E W I_{\text {inh }}\left(\mu \mathrm{Sv} \text { year }^{-1}\right)=C_{\text {air }} \cdot R \cdot T \cdot Đ
\end{aligned}
$$

From Eq. 1, $E W I_{i n g}$ is the effective dose from ingestion $\left(\mu \mathrm{Sv}\right.$ year $\left.^{-1}\right), C R_{n} W$ is the radon concentration in $\mathrm{Bq} \mathrm{L}^{-1}$, $C W$ are the estimated weight of used water found to be 100,75 and $60 \mathrm{~L} \mathrm{year}^{-1}$ ) by infants, children and adults respectively and $E D C$ is the effective dose coefficient for ingestion $\left(3.5 \mathrm{n} \mathrm{Sv} \mathrm{Bq}^{-1}\right)$.

From Eq. 2, $E W I_{i n h}$ is the effective dose of inhalation, $R$ is the ratio of radon in air to radon in spring water $\left(10^{-4}\right), C_{\text {air }}$ is the radon concentration in $\mathrm{Bq} \mathrm{L}^{-1}, F$ is the equilibrium factor between radon and its decay products (0.4), $T$ is the average indoor occupancy time per person $\left(7000 \mathrm{~h} \mathrm{year}^{-1}\right.$ ), and $Ð$ is the dose conversion factor for radon exposure $\left[9 \mathrm{n} \mathrm{Sv} \mathrm{h}^{-1}\left(\mathrm{~Bq} \mathrm{~m}^{-3}\right)^{-1}\right]$. The contribution of the dose to the lungs and stomach is calculated by multiplying the inhalation and ingestion dose by a tissue weighting factor for lung (0.12) and stomach (0.12) (ICRP 2012).

\section{Evaluation of physico-chemical properties Heavy metals}

The occurrence of heavy metals in soil and sediment could due to natural sources such as dissolution of naturally occurring minerals containing trace elements in the soil and sediments in the area (Faweya and Farai 2006; Faweya 2007; Faweya and Babalola 2010; Faweya et al. 2013). The heavy metals most frequently encountered in soil and sediment are Arsenic, Cadmium, Copper, Chromium, Zinc, Nickel, Iron, Cobalt and Manganese (Kumar et al. 2017a; Zhang et al. 2011; Song et al. 2015). Drinking water containing high levels of these harmful metals in bottom sediment and using the sediment for other purposes may be hazardous to health.

\section{Enrichment factor (EF) and geo-accumulation index $\left(\mathrm{I}_{\text {geo }}\right)$ analysis}

The sediments quality and metal contamination in the cold and warm springs were assessed using enrichment factor and geo-accumulation index. Variation in metal concentrations can be identified through EF by using geochemical normalization of the heavy metals data to conservative elements such as $\mathrm{Al}, \mathrm{Si}$ or Fe (Zhang et al. 2009; Ghrefat et al. 2011). In the present study the EF was determined based on Fe which was used as a conservative tracer to evaluate the anthropogenic impact in order to differentiate natural from anthropogenic components.

Mathematically, EF is expressed as follows

$$
E F=\frac{\left(\frac{M}{F e}\right)_{\text {sample }}}{\left(\frac{M}{F e}\right)_{\text {background }}}
$$

where $\left(\frac{M}{F e}\right)_{\text {sample }}$ is the ratio of metal and Fe concentrations of the sample and $\left(\frac{M}{F e}\right)_{\text {background }}$ is the ratio of metal and Fe concentrations of a background, the background values used were $46,700 \mathrm{mg} \mathrm{kg}^{-1}$ for $\mathrm{Fe}, 0.3 \mathrm{mg} \mathrm{kg}^{-1}$ for $\mathrm{Cd}, 45 \mathrm{mg} \mathrm{kg}^{-1}$ for $\mathrm{Cu}, 20 \mathrm{mg} \mathrm{kg}^{-1}$ for $\mathrm{Pb}$ and $68 \mathrm{mg} \mathrm{kg}^{-1}$ for Ni respectively (Turekian and wedepohl 1961; Faweya et al. 2013). Degrees of enrichment are defined as; $1 \leq \mathrm{EF}<3$, minor enrichment; $3 \leq \mathrm{EF}<5$, moderate enrichment; $5 \leq \mathrm{EF}<10$, moderately severe enrichment; $10 \leq \mathrm{EF}<25$, severe enrichment $25 \leq \mathrm{EF}<50$, very severe enrichment; and EF > 50 extremely severe enrichment.

Another criterion commonly used to evaluate the heavy metal pollution in sediment is the geo-accumulation index. The index of geo-accumulation gives the assessment of contamination by comparing the current and pre-industrial concentrations (Muller 1969). The equation used for the calculation of $\mathrm{I}_{g e o}$ is expressed as follow:

$$
I_{g e o}=\log _{2}\left(C_{n} / 1.5 B_{n}\right)
$$

where $C_{n}$ is the measured concentration for the metal in the sediments and $B_{n}$ is background value of the metal, and the factor 1.5 is used because of possible variations of the background data due to lithological variations. The geo-accumulation index has seven grades. The grades are as follows: $I_{\text {geo }} \leq 0$, uncontaminated; $0<I_{\text {geo }} \leq 1$, uncontaminated/moderately contaminated; $2<I_{\text {geo }} \leq 3$, moderately/strongly contaminated; $3<I_{\text {geo }} \leq 4$, strongly contaminated $4<I_{g e o} \leq 5$ strongly/extremely contaminated $5 \leq I_{g e o}$, extremely contaminated.

\section{Contamination factor, degree of contamination and pollution load index}

Contamination factor $C_{f}^{i}$ is the ratio of toxicity of a heavy

metal in the environment. It was calculated using the equation proposed by Hakanson (1980);

$$
C_{f}^{i}=C^{i} / C_{n}^{i}
$$


where $C^{i}$ is the mean concentration of metal $i$ in the sediments and $C_{n}^{i}$ is the background concentration of metal $i$. The following criteria are used to describe the values of the contamination factor; $C_{f}^{i}<1$ low contamination factor $1 \leq C_{f}^{i}<3$, moderate contamination factor; $3 \leq C_{f}^{i}<6$, considerable contamination factor; and $C_{f}^{i} \geq 6$, very high contamination factor (Turekian and Wedepohl 1961; Hakanson 1980).

The pollution load index is a simple way of measuring the degree of metal pollution in a studied medium (Tomlinson et al. 1980). It is expressed as

$$
P L I=\left(C_{f 1}^{i} \cdot C_{f}^{i} \cdot C_{f}^{i}\right)^{\frac{1}{n}}
$$

where $n$ is the number of metals and $C_{f}^{i}$ is the contamination factor. The pollution load Index can be classified as $(\mathrm{PLI}<1)$, no pollution; $(1<\mathrm{PLI}<2)$, moderate pollution; $(2<\mathrm{PLI}<3)$, heavy pollution and $(3<\mathrm{PLI})$, extremely heavy pollution (Banerjee and Gupta 2012).

\section{Quantification of contamination and quality of sediment}

The index $\mathrm{Q}_{0} \mathrm{C}$ as proposed by Asaah (Asaah et al. 2006) majorly defines the quantification of anthropogenic concentration of metal using the concentration in the background metal to represent the lithogenic material. It was calculated in the sediment samples using the following relation.

$$
\mathrm{QoC}(\%)=\left(\frac{C_{X}-C_{n}}{C_{X}}\right) \cdot 100
$$

Where $C_{X}$ is the average concentration of metal and $C_{n}$ is the average concentration of the metal in the background (Asaah et al. 2006), the value in percentage will determine if the impact is geogenic (negative values) or anthropogenic (positive values).

Since Nigeria has not established sediment quality guidelines at this time, the sediment quality criteria as used by (Zarei et al. 2014; Stephen et al. 2004; Orkun et al. 2011; Cevik et al. 2009) was used to classify sediment samples with regard to their potential toxicity.

In this study, sediment from cold and warm springs are compared with guidelines and global baseline values such as threshold effect level (TELs), effect range low values (ERLs), probable effect levels (PELs), effect range median values (ERMs), mean earth crust (MECs), mean world sediments (MWSs) and mean continental shale (MCSs).

\section{Results and discussion}

\section{Radon concentration}

The mean activity concentration of radon in bottled, cold and warm water samples as seen in the ninth and fourth columns of Tables 1 and 2 and ranged from 0.07 to 0.36 with an overall mean value $0.20 \mathrm{~Bq} \mathrm{~L} \mathrm{~L}^{-1}, 35-210$ with an overall mean value $75.9 \mathrm{~Bq} \mathrm{~L}^{-1}$ and $11.7-140.0$ with an overall mean value $79.4 \mathrm{~Bq} \mathrm{~L}^{-1}$ for bottled, cold and warm water samples respectively. The radon concentration was higher than $100 \mathrm{~Bq} \mathrm{~L}^{-1}$ recommended by WHO in $\mathrm{C}_{5}, \mathrm{C}_{6}, \mathrm{~W}_{3}, \mathrm{~W}_{4}, \mathrm{~W}_{5}$ and $\mathrm{W}_{10}$. The higher values found in cold and warm spring were due to uranium content of the bed rocks which easily interact with water by the effect of lithostatic pressure (Toscani et al. 2001).

Among the samples, six samples (24\%) showed radon concentration exceeding the maximum contamination level for radon in water for human consumption as suggested by EU (2001) and WHO (2011). The mean concentration of radon in bottled water was below $11 \mathrm{~Bq} \mathrm{~L}^{-1}, 100 \mathrm{~Bq} \mathrm{~L}{ }^{-1}$ recommended by USEPA (1991), EU and WHO indicating the safety of bottled water for consumption. The maximum concentrations of radon in some of the samples in study such as $\mathrm{C}_{3}(105), \mathrm{C}_{5}(210)$, $\mathrm{C}_{6}(220), \mathrm{C}_{7}(105), \mathrm{C}_{8}(176) \mathrm{C}_{9}(105), \mathrm{C}_{10}(140), \mathrm{W}_{1}(105)$ $\mathrm{W}_{3}$ (175), $\mathrm{W}_{4}(175), \mathrm{W}_{5}(140), \mathrm{W}_{7}(105), \mathrm{W}_{9}(140)$ and $\mathrm{W}_{10}(175) \mathrm{Bq} \mathrm{L}^{-1}$ were lower than maximum concentrations obtained at Mysore city India $435 \mathrm{~Bq} \mathrm{~L}^{-1}$ (Chandrashekara et al. 2012). Kumaun Himalayan region India $392 \mathrm{~Bq} \mathrm{~L}^{-1}$ (Bourai et al. 2012) Kamuan India $336 \mathrm{~Bq} \mathrm{~L}^{-1}$ (Yogesh et al. 2009), Virginia and Maryland US $296 \mathrm{~Bq} \mathrm{~L}^{-1}$ (Mose et al. 1990), Baoji China $127 \mathrm{~Bq} \mathrm{~L}^{-1}$, (Xinwei 2006) and Sankey Tank area India 381.2 Bq L ${ }^{-1}$ (Ravikumar and somashekar 2014).

\section{Annual effective dose rate}

Table 1 shows annual effective dose rate to different age classification as recommended by ICRP using their average annual consumption rate. ICRP age classification of $0-1$ years, $1-2$ years, $2-7$ years, $7-12$ years, $12-17$ years and 17 year-above in bottled water have annual effective dose rate which is $0.1 \%$ of the $1 \mathrm{mSv}$ year $^{-1}$ recommended by UNSCEAR and WHO for public. The calculated values were well below the reference level and hence bottled water does not pose any health problems from radon dose received from drinking bottled water. It suffices to say that radon with half-life 3.8 days must have decayed during the processing, bottling and storage of bottled water.

Annual effective dose rate values ranged from 0.04 to $0.20 \mathrm{mSv}$ year $^{-1}$ with a mean value $0.08 \mathrm{mSv}_{\text {year }}{ }^{-1}$ and $0.02-0.14$ with a mean $0.07 \mathrm{mSv}$ year $^{-1}$ for age classification 1 . For age classification 2, its values varied from 0.05 to $0.27 \mathrm{mSv}_{\text {year }}{ }^{-1}$ with an average value of $0.09 \mathrm{mSv}$ year $^{-1}$ and $0.02-0.182 \mathrm{mSv}$ year $^{-1}$ with average value $0.10 \mathrm{mSv}$ year $^{-1}$. The corresponding annual effective dose rate for age classification 3 ranged from 0.053 


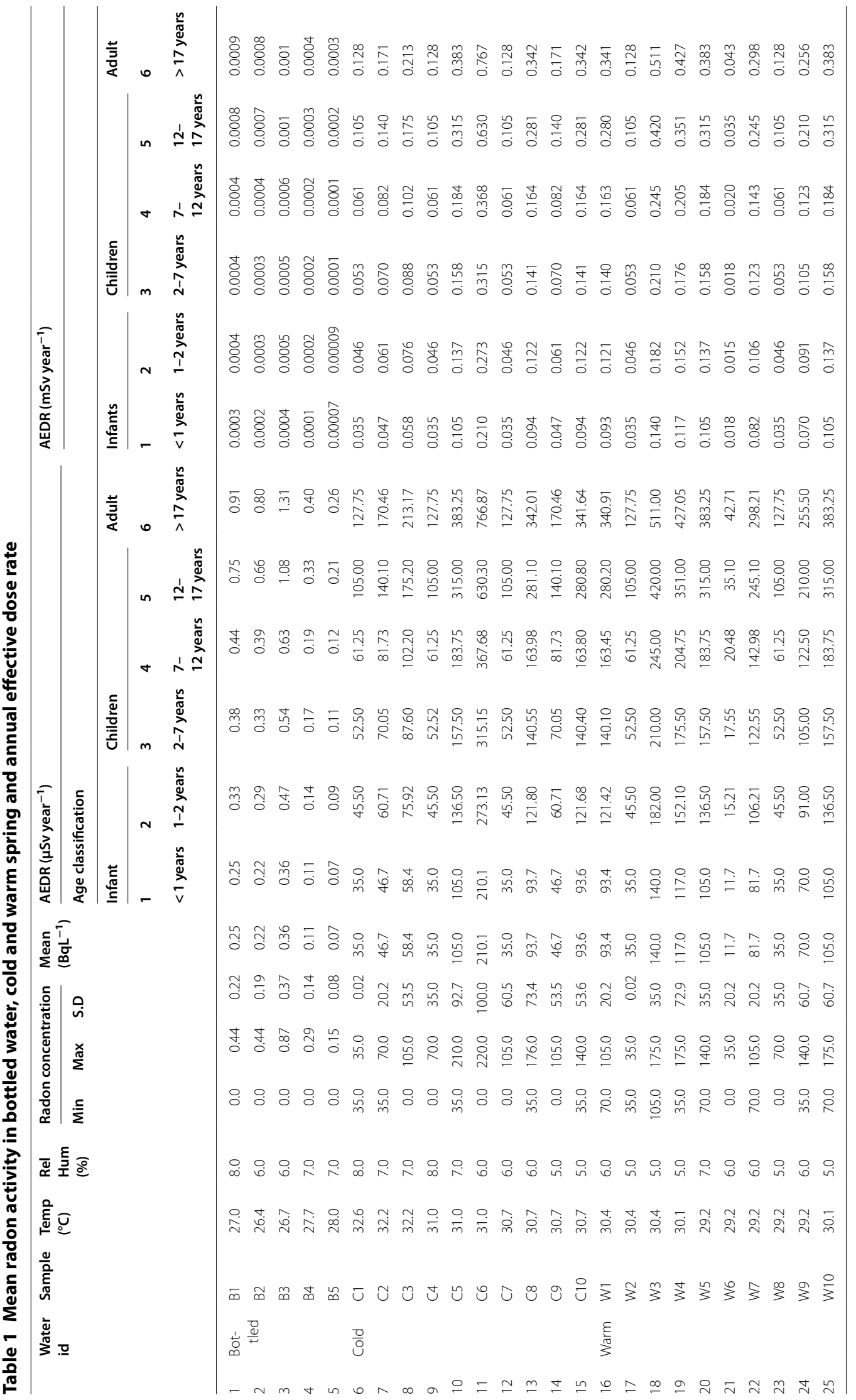


Table 2 Annual effective dose rate contribution to lungs and stomachs

\begin{tabular}{|c|c|c|c|c|c|c|c|c|c|c|c|c|c|c|}
\hline & \multirow[t]{2}{*}{ Water id } & \multirow[t]{2}{*}{ Sample } & \multirow[t]{2}{*}{ Mean $\left(\mathrm{Bq} \mathrm{L}^{-1}\right)$} & \multicolumn{3}{|c|}{ Ingestion $\left(\mu \mathrm{Sv}\right.$ year $\left.^{-1}\right)$} & \multirow[t]{2}{*}{$\begin{array}{l}\text { Inhalation } \\
\left(\mu \mathrm{Sv} \text { year }^{-1}\right)\end{array}$} & \multirow[t]{2}{*}{ Lungs } & \multicolumn{3}{|c|}{ Stomach $\left(\mu \mathrm{Sv}\right.$ year $\left.{ }^{-1}\right)$} & \multicolumn{3}{|c|}{$\begin{array}{l}\text { Total effective dose } \\
\left(\mu \mathrm{Sv} \text { year }^{-1}\right)\end{array}$} \\
\hline & & & & Infant & Children & Adult & & & Infant & Children & Adult & Infant & Children & Adult \\
\hline 1 & \multirow[t]{5}{*}{ Bottled } & B1 & 0.25 & 0.09 & 0.07 & 0.05 & 0.63 & 0.08 & 0.01 & 0.008 & 0.006 & 0.09 & 0.088 & 0.086 \\
\hline 2 & & B2 & 0.22 & 0.08 & 0.06 & 0.05 & 0.55 & 0.07 & 0.01 & 0.007 & 0.006 & 0.08 & 0.077 & 0.076 \\
\hline 3 & & B3 & 0.36 & 0.13 & 0.09 & 0.08 & 0.91 & 0.11 & 0.02 & 0.010 & 0.010 & 0.130 & 0.120 & 0.120 \\
\hline 4 & & B4 & 0.11 & 0.04 & 0.03 & 0.02 & 0.28 & 0.03 & 0.005 & 0.004 & 0.003 & 0.035 & 0.034 & 0.033 \\
\hline 5 & & B5 & 0.07 & 0.03 & 0.02 & 0.01 & 0.17 & 0.02 & 0.004 & 0.003 & 0.002 & 0.024 & 0.023 & 0.022 \\
\hline 6 & \multirow[t]{10}{*}{ Cold } & $\mathrm{C} 1$ & 35.0 & 12.25 & 9.19 & 7.35 & 88.20 & 10.58 & 1.47 & 1.10 & 0.88 & 12.05 & 11.68 & 11.46 \\
\hline 7 & & $\mathrm{C} 2$ & 46.7 & 16.35 & 12.26 & 9.81 & 117.70 & 14.12 & 1.96 & 1.47 & 1.18 & 16.08 & 15.59 & 15.3 \\
\hline 8 & & $\mathrm{C} 3$ & 58.4 & 20.44 & 15.33 & 12.26 & 147.20 & 17.66 & 2.45 & 1.84 & 1.47 & 20.11 & 19.50 & 19.13 \\
\hline 9 & & C4 & 35.0 & 12.25 & 9.19 & 7.35 & 88.20 & 10.58 & 1.47 & 1.10 & 0.88 & 12.05 & 11.68 & 11.46 \\
\hline 10 & & C5 & 105.0 & 36.75 & 27.56 & 22.05 & 264.60 & 31.75 & 4.41 & 3.31 & 2.65 & 36.16 & 35.06 & 34.40 \\
\hline 11 & & C6 & 210.1 & 73.54 & 55.16 & 44.13 & 529.50 & 63.54 & 8.82 & 6.62 & 5.30 & 72.36 & 70.16 & 68.84 \\
\hline 12 & & $\mathrm{C} 7$ & 35.0 & 12.25 & 9.19 & 7.35 & 88.20 & 10.58 & 1.47 & 1.10 & 0.88 & 12.05 & 11.68 & 11.46 \\
\hline 13 & & $\mathrm{C} 8$ & 93.7 & 32.80 & 24.60 & 19.68 & 236.12 & 28.33 & 3.94 & 2.95 & 2.36 & 32.27 & 31.28 & 30.69 \\
\hline 14 & & C9 & 46.7 & 16.35 & 12.26 & 9.81 & 117.70 & 14.12 & 1.96 & 1.47 & 1.18 & 16.08 & 15.59 & 15.30 \\
\hline 15 & & C10 & 93.6 & 32.76 & 24.57 & 19.67 & 235.87 & 28.30 & 3.95 & 2.95 & 2.35 & 32.25 & 31.25 & 30.65 \\
\hline 16 & \multirow[t]{10}{*}{ Warm } & W1 & 93.4 & 32.69 & 24.52 & 19.61 & 235.37 & 28.24 & 3.92 & 2.94 & 2.34 & 32.16 & 31.18 & 30.58 \\
\hline 17 & & W2 & 35.0 & 12.25 & 9.19 & 7.35 & 88.20 & 10.58 & 1.47 & 1.10 & 0.88 & 12.05 & 11.68 & 11.46 \\
\hline 18 & & W3 & 140.0 & 49.00 & 36.75 & 29.40 & 352.80 & 42.34 & 5.88 & 4.41 & 3.53 & 48.22 & 46.75 & 45.87 \\
\hline 19 & & W4 & 117.0 & 40.95 & 30.71 & 24.57 & 294.60 & 35.38 & 4.91 & 3.69 & 2.95 & 40.29 & 39.07 & 38.33 \\
\hline 20 & & W5 & 105.0 & 36.75 & 27.56 & 22.05 & 264.60 & 31.75 & 4.41 & 3.31 & 2.65 & 36.16 & 35.06 & 34.40 \\
\hline 21 & & W6 & 11.7 & 4.09 & 3.07 & 2.46 & 29.48 & 3.54 & 0.49 & 0.37 & 0.30 & 4.03 & 3.91 & 3.84 \\
\hline 22 & & W7 & 81.7 & 28.60 & 21.45 & 17.16 & 205.88 & 24.71 & 3.43 & 2.57 & 2.06 & 28.14 & 27.28 & 26.77 \\
\hline 23 & & W8 & 35.0 & 12.25 & 9.19 & 7.35 & 88.20 & 10.58 & 1.47 & 1.10 & 0.88 & 12.05 & 11.68 & 11.46 \\
\hline 24 & & W9 & 70.0 & 24.50 & 18.38 & 14.70 & 176.40 & 21.17 & 2.94 & 2.21 & 1.76 & 24.11 & 23.38 & 22.93 \\
\hline 25 & & W10 & 105.0 & 36.75 & 27.56 & 22.05 & 264.60 & 31.75 & 4.41 & 3.31 & 2.65 & 36.16 & 35.06 & 34.40 \\
\hline
\end{tabular}

to $0.315 \mathrm{mSv}$ year ${ }^{-1}$ and 0.053 to $0.21 \mathrm{mSv}$ year $^{-1}$ with average value 0.11 and $0.12 \mathrm{mSv}$ year $^{-1}$. For age classification 4 , it varied from 0.061 to $0.368 \mathrm{mSv}_{\text {year }}{ }^{-1}$ with average value $0.133 \mathrm{mSv}$ year $^{-1}$ and $0.061-$ $0.245 \mathrm{mSv}$ year ${ }^{-1}$ with average value $0.139 \mathrm{mSv}$ year $^{-1}$. The estimated values of annual effective dose rate for age classification 5 oscillated from 0.105 to $0.630 \mathrm{mSv}_{\text {year }}{ }^{-1}$ with an average value of $0.238 \mathrm{mSv}$ year $^{-1}$ and $0.035-$ $0.420 \mathrm{mSv}$ year ${ }^{-1}$ with average value $0.238 \mathrm{mSv}_{\text {year }}{ }^{-1}$ and varied from 0.128 to $0.767 \mathrm{mSv}$ year $^{-1}$ with average $0.277 \mathrm{mSv}_{\text {year }}{ }^{-1} ; 0.043-0.511 \mathrm{mSv}$ year ${ }^{-1}$ with average value $0.290 \mathrm{mSv}$ year $^{-1}$ for age classification 6 for both cold and warm water samples respectively. The mean values were far below $1 \mathrm{mSv}$ year $^{-1}$ recommended by UNSCEAR and WHO for member of public.

The present study revealed that the annual effective dose rate values increased with respect to radon activity, age and water consumption rates. The annual effective dose rate received by ICRP age classifications of $1<2<3<4<5<6$. All the samples have annual effective dose rate values that were significantly lower than

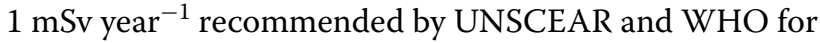
member of public.

\section{Inhalation and ingestion dose and effect on stomach and lungs}

The annual effective dose rate values received by stomach in columns 5, 6 and 7 due to ingestion from bottled water varied from 0.03 to $0.13 \mu \mathrm{Sv}$ year $^{-1}, 0.02$ to $0.09 \mu \mathrm{Sv}$ year $^{-1}, 0.01$ to $0.08 \mu \mathrm{Sv}$ year $^{-1}$ with mean values $0.04,0.03$ and $0.02 \mu \mathrm{Sv}$ year $^{-1}$ for infants, children and adults respectively. While annual effective dose rate values received by lungs due to inhalation of radon released from bottled water in column 8 ranged from 0.17 to 0.95 with a mean value $0.51 \mu \mathrm{Sv}$ year $^{-1}$. For cold water samples, the values received by stomach in columns 5, 6 and 7 of Table 2 due to consumption of cold water samples varied from 35.0 to $210.1 \mu \mathrm{Sv}$ year $^{-1}$, 12.25 to $73.54 \mu \mathrm{Sv}$ year $^{-1}, 9.19$ to $55.16 \mu \mathrm{Sv}$ year $^{-1}, 7.35$ to $44.13 \mu \mathrm{Sv}$ year ${ }^{-1}$ with mean values $26.57,19.93$ and $15.95 \mu \mathrm{Sv}$ year $^{-1}$ for infant, children and adult respectively; while its values received by lungs due to inhalation 
of radon ranged from 88.20 to $529.5 \mu \mathrm{Sv}$ year ${ }^{-1}$ with mean value $191.33 \mu \mathrm{Sv}$ year $^{-1}$. For warm water samples, annual effective dose rate values received by stomach ranged from 4.09 to $49.00 \mu \mathrm{Sv}$ year $^{-1}, 3.07$ to $36.75 \mu \mathrm{Sv}$ year ${ }^{-1}, 2.46$ to $29.40 \mu \mathrm{Sv}$ year $^{-1}$ with mean values $27.78,20.84$ and $16.67 \mu \mathrm{Sv}_{\text {year }}{ }^{-1}$ for infant, children and adult respectively; while annual effective dose rate for lungs varied from 29.48 to $352.80 \mu \mathrm{Sv}$ year $^{-1}$ with average value $200.1 \mu \mathrm{Sv}$ year $^{-1}$.

The contribution of the dose to the lungs and stomach was calculated by multiplying the inhalation and ingestion dose by a tissue weighing factor 0.12 for lung and stomach (ICRP 2012). The results obtained are shown in ninth, tenth, eleventh and twelfth columns of Table 2 for lungs and stomach respectively.

The annual effective dose rate values received by lungs due to inhalation from bottled, cold and hot spring water varied from 0.02 to $0.11 \mu \mathrm{Sv}$ year ${ }^{-1}$ with mean value $0.06 \mu \mathrm{Sv}$ year $^{-1}$; 10.58 to $63.54 \mu \mathrm{Sv}$ year ${ }^{-1}$ with mean value $22.96 \mu \mathrm{Sv}$ year $^{-1}$ and 3.54 to $42.34 \mu \mathrm{Sv}$ year $^{-1}$ with a mean $24.00 \mu \mathrm{Sv}$ year $^{-1}$ respectively.

Annual effective dose rate values received by stomach due to consumption of water by infant, children and adult varied from 0.004 to $0.02 \mu \mathrm{Sv}$ year $^{-1}$ with mean $0.01 \mu \mathrm{Sv}$ year ${ }^{-1} ; 0.003$ to $0.01 \mu \mathrm{Sv}$ year $^{-1}$ with mean $0.01 \mu \mathrm{Sv}$ year ${ }^{-1} ; 0.002$ to $0.01 \mu \mathrm{Sv}$ year $^{-1}$ with mean $0.01 \mu \mathrm{Sv}$ year $^{-1}$ respectively for bottled water. The values for infant, children and adult ranged from 1.47 to $8.82 \mu \mathrm{Sv}$ year $^{-1}$ with a mean $3.19 \mu \mathrm{Sv}$ year $^{-1}$; 0.49 to $5.88 \mu \mathrm{Sv}$ year $^{-1}$ with mean $3.33 \mu \mathrm{Sv}$ year $^{-1} ; 1.10$ to $6.62 \mu \mathrm{Sv}$ year $^{-1}$ with mean $2.50 \mu \mathrm{Sv}$ year $^{-1}$; 0.88 to $5.30 \mu \mathrm{Sv}$ year $^{-1}$ with mean $2.00 \mu \mathrm{Sv}$ year $^{-1}$ for cold and warm spring respectively. The results show that dose contribution to lungs was higher than dose contributed to the stomach. The results agreed with that of radon found in drinking water in India, that indicate dose contribution to lungs higher than dose contribution to stomach (Kumar et al. 2017b). The calculated effective dose (whole body) due to radon inhalation and ingestion for infant, children and adult ranged from 0.024 to $0.13 \mu \mathrm{Sv}$ year $^{-1}$ with a mean value $0.07 \mu \mathrm{Sv}$ year $^{-1}$; 0.023 to $0.12 \mu \mathrm{Sv}$ year $^{-1}$ with a mean value $0.07 \mu \mathrm{Sv}$ year $^{-1} ; 0.022$ to $0.12 \mu \mathrm{Sv}$ year ${ }^{-1}$ with a mean value $0.07 \mu \mathrm{Sv}$ year $^{-1}$ respectively for bottled water. It ranged from 12.05 to $72.36 \mu \mathrm{Sv}$ year ${ }^{-1}$ with a mean value $26.15 \mu \mathrm{Sv}_{\text {vear }}{ }^{-1}$; 4.03 to $48.22 \mu \mathrm{Sv}$ year ${ }^{-1}$ with a mean value $27.94 \mu \mathrm{Sv}$ year $^{-1}$; 11.68 to $70.16 \mu \mathrm{Sv}$ year $^{-1}$ with a mean value $25.35 \mu \mathrm{Sv}$ year $^{-1}$; 3.91 to $46.75 \mu \mathrm{Sv}$ year ${ }^{-1}$ with a mean $24.87 \mu \mathrm{Sv}$ year $^{-1}$ and 3.84 to $45.87 \mu \mathrm{Sv}$ year ${ }^{-1}$ with a mean value $26.00 \mu \mathrm{Sv}$ year $^{-1}$, for infant, children and adult in cold and warm spring respectively. The results for risk estimates indicate that inhalation of radon accounts for $88.89 \%$ of the individual risk associated with the use of bottled, cold and warm water, while the remaining $11.11 \%$ resulting from the ingestion of radon gas. The results agreed with $89 \%$ inhalation and $11 \%$ ingestion revealed by USEPA (1999). The calculated total effective dose values were below $100 \mu \mathrm{Sv}$ year ${ }^{-1}$ which is safe limit recommended by WHO (2004) therefore, no radiological health problems is envisaged.

\section{Physico-chemical evaluation}

The concentration of metals in the cold and warm springs sediments, global baseline values and SQGs of the studied metals are presented in Tables 3 and 4 . The variations in concentration values are depicted in Fig. 2a-d (Fig. 2a bar chart of readings and spectrum for $\mathrm{Ni}, \mathrm{Cd}, \mathrm{Cu}$ and $\mathrm{Pb}$ in selected points in cold spring Fig. $2 \mathrm{~b}$ bar chart of readings and spectrum for $\mathrm{Fe}$ in selected points in cold spring Fig. 2c bar chart of readings and spectrum for $\mathrm{Ni}$, $\mathrm{Cd}, \mathrm{Cu}$ and $\mathrm{Pb}$ in selected points in warm spring Fig. $2 \mathrm{c}$ bar chart of readings and spectrum for $\mathrm{Ni}, \mathrm{Cd}, \mathrm{Cu}$ and $\mathrm{Pb}$ in selected points in warm spring Fig. $2 \mathrm{~d}$ bar chart of readings and spectrum for Fe in selected points in warm spring) (Additional file 1). The results in Table 3 and Fig. 2b, d showed that Fe had the highest concentration in the sediments. The average concentration of $\mathrm{Pb}$ ranged from $2.9 \mathrm{mg} \mathrm{kg}^{-1} \mathrm{dw}\left(\mathrm{W}_{4}\right)$ to $11.80 \mathrm{mg} \mathrm{kg}^{-1} \mathrm{dw}$ $\left(\mathrm{C}_{6}\right)$ respectively. A comparison of $\mathrm{Pb}$ highest concentration in sediments with the corresponding values of this metal in ERL, ERM, TEL, MEC, PEL, MWS and MCS showed that the levels of $\mathrm{Pb}$ were lower (3.9 8 times) than ERL, ERM (18.64 times) TEL (2.56 times), PEL (9.49 times), MEC(1.19 times), MWS (1.61 times) and MCS (1.69 times). The highest and lowest mean concentrations of $\mathrm{Cu}$ in sediments were found to be 3.80 and $12.80 \mathrm{mg} \mathrm{kg}^{-1} \mathrm{dw}$, respectively; The average concentrations of Fe in sediments in ranged from $945\left(C_{5}\right)$ to $2010 \mathrm{mg} \mathrm{kg}^{-1} \mathrm{dw}\left(\mathrm{W}_{3}\right)$. The lowest and highest concentrations of Fe in the sediments were below the MCS. The highest and lowest concentrations of $\mathrm{Cd}$ in the sediment were 0.6 and $1.7 \mathrm{mg} \mathrm{kg}^{-1} \mathrm{dw}$.

The comparison of $\mathrm{Cd}$ highest concentration with the studied standard values showed that the levels of $\mathrm{Cd}$ were lower than (2.47 times) PEL, (5.67 times) MCS, (5.64 times) ERM, (1.42 times) ERL, (2.43 times) TEL. In the studied sediments the highest mean concentration of $\mathrm{Ni} 2.60 \mathrm{mg} \mathrm{kg}^{-1} \mathrm{dw}$ was lower than ERL (88\%), ERM (95\%) and MCS (96\%) respectively. The differences in the level of metals in the sediments of cold and warm springs of Ikogosi may be due to parameters such as $\mathrm{pH}$, organic matter and environmental factors which control the solubility and availability of metals (Ebrahimpour and Mushrifah 2008). The resulting EF values in Table 4 showed that $\mathrm{Pb}, \mathrm{Cu}$ and $\mathrm{Cd}$ are enriched in the sediment samples while there is no $\mathrm{Ni}$ enrichment in both 


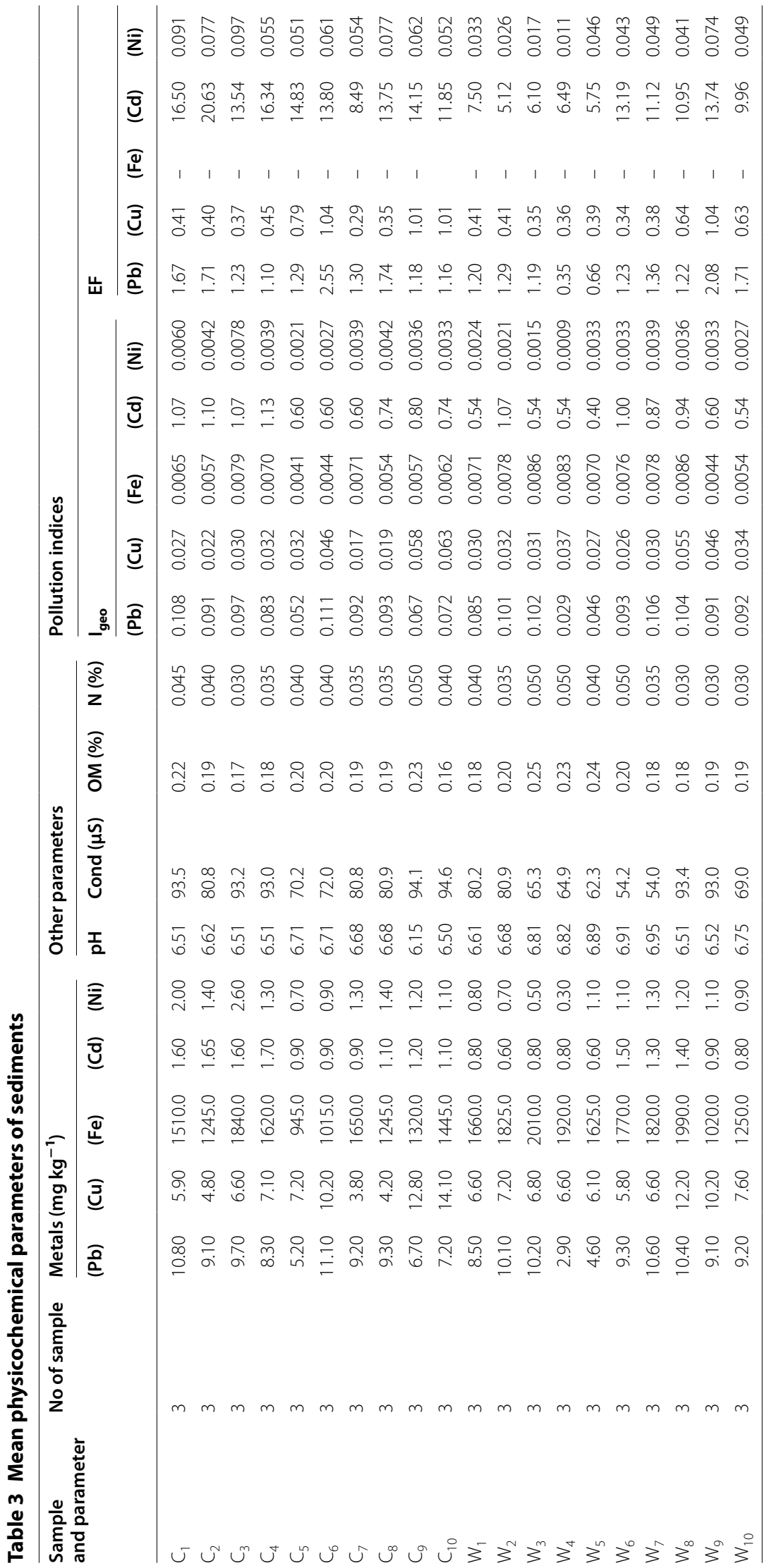


Table 4 Contamination factor, pollution load index, quantification of contamination and sediment quality guidelines

\begin{tabular}{|c|c|c|c|c|c|c|c|c|c|c|c|}
\hline \multirow{2}{*}{$\begin{array}{l}\text { Sample } \\
\text { and parameter }\end{array}$} & \multicolumn{4}{|l|}{$c_{f}^{i}$} & \multicolumn{2}{|l|}{ PLI } & \multicolumn{5}{|l|}{$Q_{0} C(\%)$} \\
\hline & $\overline{\mathrm{Pb}}$ & $\mathrm{Cu}$ & $\mathrm{Fe}$ & $C d$ & $\mathrm{Ni}$ & & $\mathrm{Pb}$ & $\mathrm{Cu}$ & $\mathrm{Fe}$ & $\mathrm{Cd}$ & $\mathrm{Ni}$ \\
\hline$C_{1}$ & 0.54 & 0.13 & 0.03 & 5.33 & 0.03 & 0.20 & -85.19 & -662.71 & -2992.72 & 81.25 & -330.00 \\
\hline$C_{2}$ & 0.46 & 0.11 & 0.03 & 5.50 & 0.02 & 0.18 & -119.78 & -837.50 & -3651.00 & 81.82 & -4757.1 \\
\hline$C_{3}$ & 0.49 & 0.15 & 0.04 & 5.33 & 0.04 & 0.23 & -106.19 & -581.82 & -2438.04 & 81.25 & -2515.38 \\
\hline $\mathrm{C}_{4}$ & 0.42 & 0.16 & 0.03 & 5.67 & 0.02 & 0.19 & -140.96 & -533.80 & -2787.70 & 82.35 & -5130.77 \\
\hline$C_{5}$ & 0.26 & 0.16 & 0.02 & 3.00 & 0.01 & 0.12 & -284.62 & -525.00 & -4841.70 & 66.67 & -9614.29 \\
\hline $\mathrm{C}_{6}$ & 0.56 & 0.23 & 0.02 & 3.00 & 0.01 & 0.15 & -79.28 & -341.18 & -4500.99 & 66.67 & -7455.56 \\
\hline$C_{7}$ & 0.46 & 0.08 & 0.04 & 3.00 & 0.02 & 0.15 & -117.39 & -1084.21 & -2730.30 & 66.67 & -5130.77 \\
\hline $\mathrm{C}_{8}$ & 0.47 & 0.09 & 0.03 & 3.67 & 0.02 & 0.16 & -115.05 & -971.43 & -3651.00 & 72.73 & -4757.14 \\
\hline $\mathrm{C}_{9}$ & 0.34 & 0.28 & 0.03 & 4.00 & 0.02 & 0.19 & -198.51 & -251.56 & -3437.88 & 75.00 & -5566.67 \\
\hline$C_{10}$ & 0.36 & 0.31 & 0.03 & 3.67 & 0.02 & 0.19 & -177.78 & -219.15 & -3131.83 & 72.73 & -6081.82 \\
\hline$W_{1}$ & 0.43 & 0.15 & 0.04 & 2.67 & 0.01 & 0.15 & -135.29 & -581.82 & -2713.25 & 62.50 & -8400.00 \\
\hline$W_{2}$ & 0.51 & 0.16 & 0.04 & 2.00 & 0.01 & 0.15 & -98.02 & -525.00 & -2458.90 & 50.00 & -9614.29 \\
\hline$W_{3}$ & 0.51 & 0.15 & 0.04 & 2.67 & 0.01 & 0.15 & -96.08 & -561.76 & -2223.38 & 62.50 & $-13,500.00$ \\
\hline$W_{4}$ & 0.15 & 0.15 & 0.04 & 2.67 & 0.00 & 0.00 & -589.66 & -581.82 & -2332.29 & 62.50 & $-22,566.60$ \\
\hline$W_{5}$ & 0.23 & 0.14 & 0.03 & 2.00 & 0.02 & 0.13 & -334.78 & -637.70 & -2773.85 & 50.00 & -6081.82 \\
\hline$W_{6}$ & 0.47 & 0.13 & 0.04 & 5.00 & 0.02 & 0.19 & -115.05 & -675.86 & -2538.42 & 80.00 & -6081.82 \\
\hline$W_{7}$ & 0.53 & 0.15 & 0.04 & 4.33 & 0.02 & 0.19 & -88.68 & -581.82 & -2465.93 & 76.92 & -5130.00 \\
\hline$W_{8}$ & 0.52 & 0.27 & 0.04 & 4.67 & 0.02 & 0.22 & -92.31 & -268.85 & -2246.73 & 78.57 & -5566.00 \\
\hline$W_{9}$ & 0.46 & 0.23 & 0.02 & 3.00 & 0.02 & 0.17 & -119.78 & -341.18 & -4478.43 & 66.67 & -6081.00 \\
\hline$W_{10}$ & 0.46 & 0.17 & 0.03 & 2.67 & 0.01 & 0.14 & -117.39 & -492.11 & -3636.00 & 62.50 & -7455.00 \\
\hline \multicolumn{12}{|c|}{ Global baseline values and sediment quality $\left(\mathrm{mg} \mathrm{kg}^{-1}\right)$} \\
\hline & \multicolumn{3}{|c|}{$\mathrm{Pb}$} & \multicolumn{2}{|r|}{$\mathrm{Cu}$} & \multicolumn{3}{|c|}{$\mathrm{Fe}$} & $\mathrm{Cd}$ & \multicolumn{2}{|c|}{$\mathrm{Ni}$} \\
\hline ERL & \multicolumn{3}{|c|}{47} & \multicolumn{2}{|r|}{34} & \multicolumn{3}{|c|}{ - } & 1.2 & \multicolumn{2}{|c|}{21} \\
\hline ERM & \multicolumn{3}{|c|}{220} & \multicolumn{2}{|r|}{270} & \multicolumn{3}{|c|}{-} & 9.6 & \multicolumn{2}{|c|}{52} \\
\hline TEL & \multicolumn{3}{|c|}{30.2} & \multicolumn{2}{|r|}{18.7} & \multicolumn{3}{|c|}{-} & 0.7 & \multicolumn{2}{|l|}{-} \\
\hline PEL & \multicolumn{3}{|c|}{112} & \multicolumn{2}{|r|}{108} & \multicolumn{3}{|c|}{-} & 4.2 & \multicolumn{2}{|l|}{ - } \\
\hline MEC & \multicolumn{3}{|c|}{14} & \multicolumn{2}{|r|}{50} & & 4.1 & & - & - & \\
\hline MWS & & 19 & & & 33 & & 4.1 & & - & - & \\
\hline MCS & & 20 & & & 45 & & 46,700 & & 0.3 & 68 & \\
\hline Present study & & 2.9 & & & $3.8-12.8$ & & 945.0-2010.0 & & $0.6-1.7$ & & in-2.6 Max \\
\hline
\end{tabular}

cold and warm springs respectively. The EF values for $\mathrm{Cd}$ are the highest among the metals and it has a very severe to severe enrichment. This is similar to research carried out by Ghrefat et al. (2011) in the sediments of Kafrain Dam, Jordan. The EF values also indicate that $\mathrm{Pb}$ has a moderate enrichment to severe enrichment, $\mathrm{Cu}$ has minor enrichment to moderately severe enrichment, and $\mathrm{Ni}$ has no enrichment. The enrichment of metals in the sediments of the springs has been observed to be relatively high in the sediments. The fluctuations in EF values of different metals in the cold and warm springs may be due to the differences in the magnitude of input for each metal in sediment and or the removal rate of each metal from the sediment as reported by Ghrefat et al. (2011). The EF values of $\mathrm{Pb}, \mathrm{Cu}$ and $\mathrm{Cd}$ that are greater than one suggest that the sources are more likely to be anthropogenic. The EF values in this study were compared with those available from other regions. The values obtained fell within results of Kafrain Dam; 10, 70, 37410, 140 and 100 (Ghrefat et al. 2011), Wadi Al-Arab Dam 9, 60, 11270 ND, ND (Ghrefat and Yusuf 2006), Seyhan Dam; 21, 198, 393500 ND, ND (Cevik et al. 2009). Ataturk Dam ND, 18.6, 15925, ND, $91.7 \mathrm{mg} \mathrm{kg}^{-1}$ (Karadede and Unlu 2000) for $\mathrm{Cd}, \mathrm{Cu}, \mathrm{Fe}, \mathrm{Pb}$ and $\mathrm{Ni}$ respectively.

The EF values show that as the values of metals vary the classification of contamination levels vary. The classification of contamination level base on $\mathrm{I}_{\text {geo }}$ does not always vary as the content of metals vary (Ghrefat et al. 2011). Therefore, the calculations of $I_{g e o}$ are more reliable than those of EF for assessing metal pollution as seen in Table 3. The geoaccumulation index results in the Table 3 show that sediments are uncontaminated to 

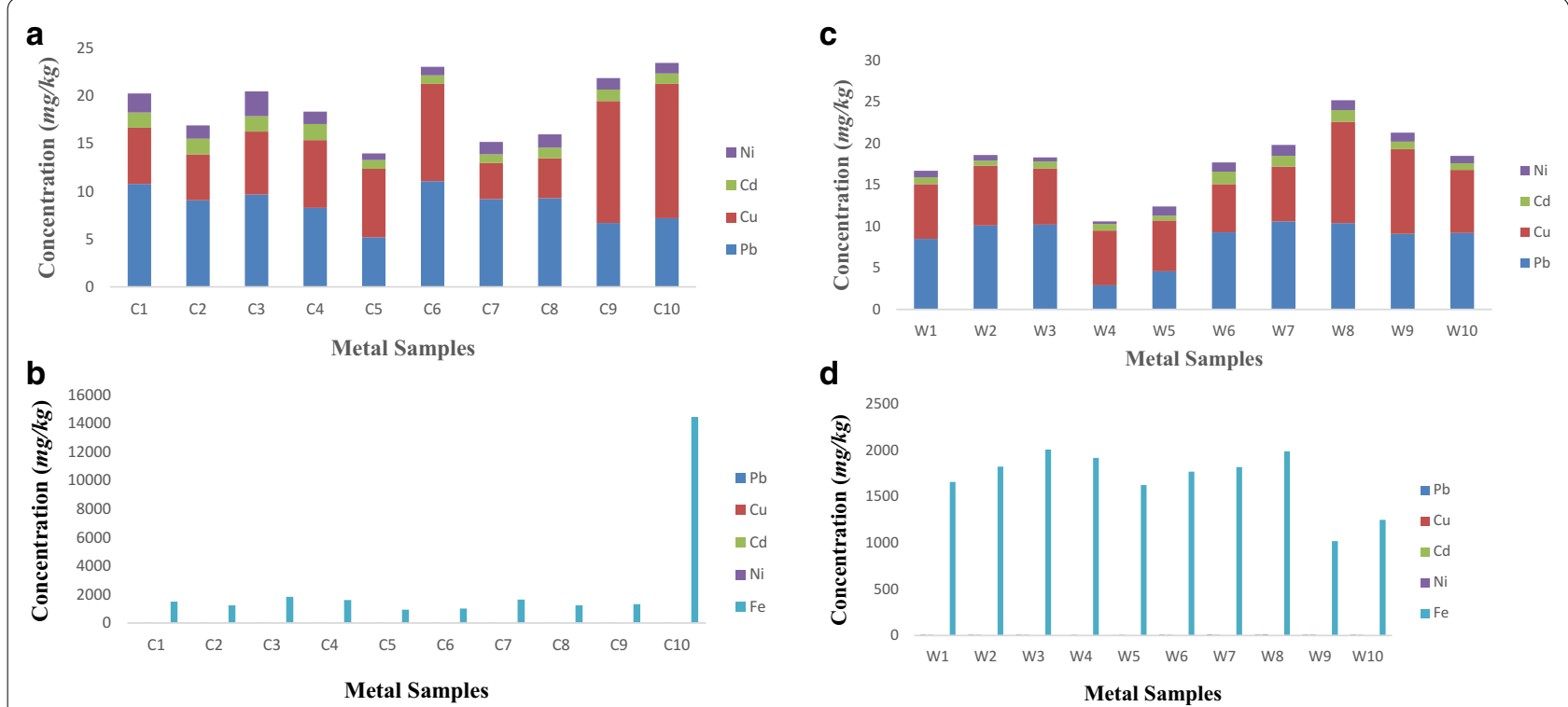

Fig. 2 a Bar chart of readings and spectrum for $\mathrm{Ni}, \mathrm{Cd}, \mathrm{Cu}$ and $\mathrm{Pb}$ in selected points in cold spring. $\mathbf{b}$ Bar chart of readings and spectrum for Fe in selected points in cold spring. $\mathbf{c}$ Bar chart of readings and spectrum for $\mathrm{Ni}, \mathrm{Cd}, \mathrm{Cu}$ and $\mathrm{Pb}$ in selected points in warm spring. $\mathbf{d}$ Bar chart of readings and spectrum for Fe in selected points in warm spring

uncontaminated/moderately contaminated. The moderately contaminated values of $\mathrm{Cd}$ in few of the samples are probably a result of anthropogenic activities. The results of the analysis of the contamination factor $C_{f}^{i}$ as proposed by Hakanson (1980) and pollution load index (PLI) (Tomlinson et al. 1980) for the studied metals are shown in Table 4. The values of $C_{f}^{i}$ revealed low contamination levels for $\mathrm{Pb}$ (0.15-0.56), $\mathrm{Cu}(0.08-0.31)$, Fe (0.02-0.04), $\mathrm{Ni}(0.01-0.04)$ and indicate from moderate contamination levels to considerable contamination levels for $\mathrm{Cd}$. The values of PLI indicated no pollution in all the studied samples at each sampling point and varied from 0.12 to 0.23 . The analysis of $\mathrm{Q}_{0} \mathrm{C}$ is normally used to describe the geogenic and anthropogenic sources of metal contamination in sediments samples (Zarei et al. 2014). Table 4 showed that the concentration of $\mathrm{Pb}, \mathrm{Cu}, \mathrm{Fe}$, and $\mathrm{Ni}$ were mainly from geogenic sources because of the negative values while the values of $\mathrm{Cd}$ showed to have anthropogenic sources of contamination in all the study points. $\mathrm{Q}_{0} \mathrm{C}$ for Cd values showed 50.00-82.35\% magnitude for anthropogenic impacts that could be from tourist activities). From the result obtained, the $\mathrm{pH}$ lies between 6.15 and $6.95,95 \%$ of the values obtained could be rounded up to 7 , which indicates the neutrality of the sediments and pure water is neutral with a $\mathrm{pH}$ 7. The neutrality in sediments of both springs was attributed to factors such as $\mathrm{CO}_{2}$ removal by photosynthesis through bicarbonate degradation and dilution of water with fresh water influx from both springs. Nitrogen in the sediments samples varied from 0.03 to $0.05 \%$. All the values obtained are almost the same; which can be attributed to the oxidation of organic matter that settled in the bottom sediment from the top layer. Positive correlation $\left(R^{2}=0.99\right)$ obtained between organic matter $(\mathrm{OM})$ and $(\mathrm{N}) \%$ revealed the contribution of organic matter. OM content varied from 0.16 to $0.25 \%$. The peak value $0.25 \%$ was obtained at point $\mathrm{W}_{3}$. The calculated values of organic matter could be attributed to dead planktonic matter which settles at the bottom, oxidized and decomposed as reported by Martin et al. (2010). The results revealed conductivity values between 54.0 and 94.6 , this is an indication that the two spring's sediments have conductivity not exceeding $150-500 \mu \mathrm{S} \mathrm{cm}^{-1}$ ideally for freshwater as reported by Sharon and Montpelier (1997).

\section{Statistical analysis}

Pearson's correlation coefficients for $\mathrm{Pb}, \mathrm{Cu}, \mathrm{Fe}, \mathrm{Cd}, \mathrm{Ni}$ and $\mathrm{pH}$ values in the sediments samples of both springs are shown in Table 5. The matrix showed the strength of the linear correlation. The linear correlation coefficients showed that there is positive correlation between $\mathrm{Pb}$ and $\mathrm{Ni}(\mathrm{r}=0.66, \mathrm{P}<0.05)$, Fe and $\mathrm{Ni}(\mathrm{r}=0.76, \mathrm{P}<0.05)$, $\mathrm{Cd}$ and $\mathrm{Ni}(\mathrm{r}=0.66, \mathrm{P}<0.05)$ in cold spring. The positive correlation revealed the possibility of the same source of pollutants (Khuzestani and Souri 2013). Positive correlation $(\mathrm{r}=0.57, \mathrm{P}<0.05)$ was obtained between $\mathrm{Cd}$ and $\mathrm{Ni}$ in the warm spring, while negative correlation $(\mathrm{r}=-0.81, \mathrm{P}<0.01)$ was obtained between $\mathrm{Cu}$ and 
Faweya et al. Environ Syst Res (2018) 7:22

Page 13 of 17

Table 5 Correlation analysis for metals in the warm and cold springs sediments $* P<0.05 * \boldsymbol{P}<0.01$

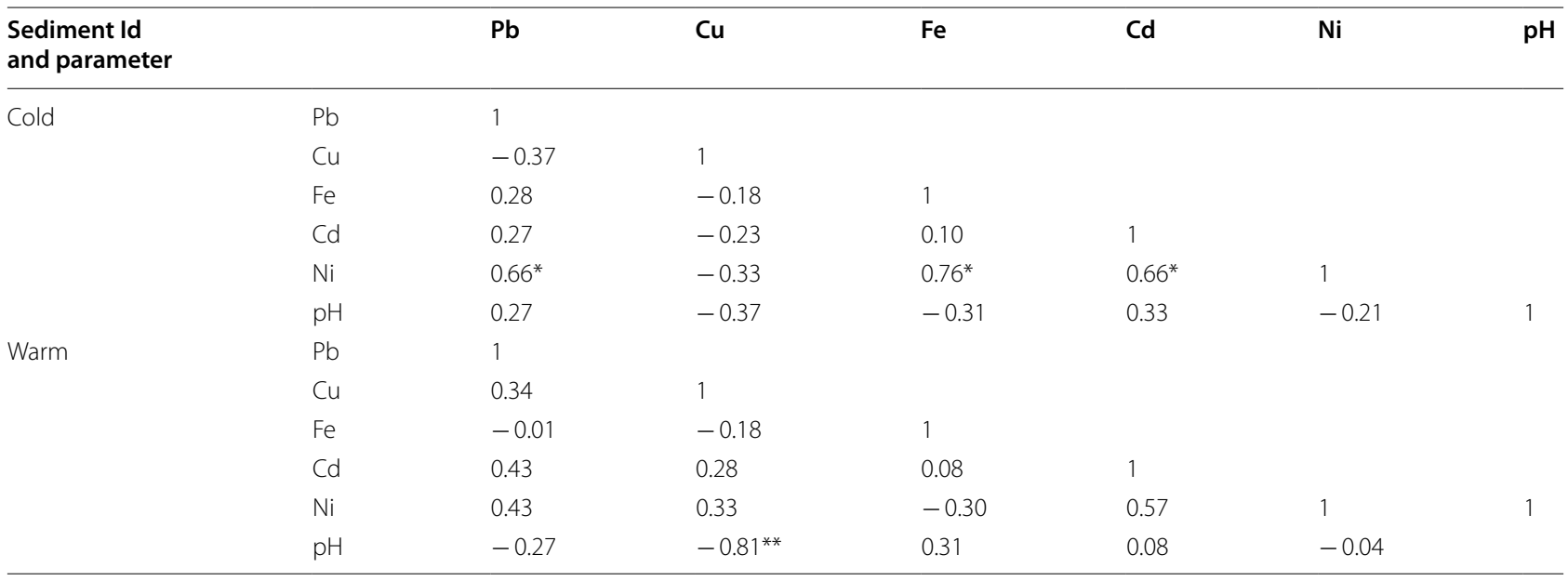

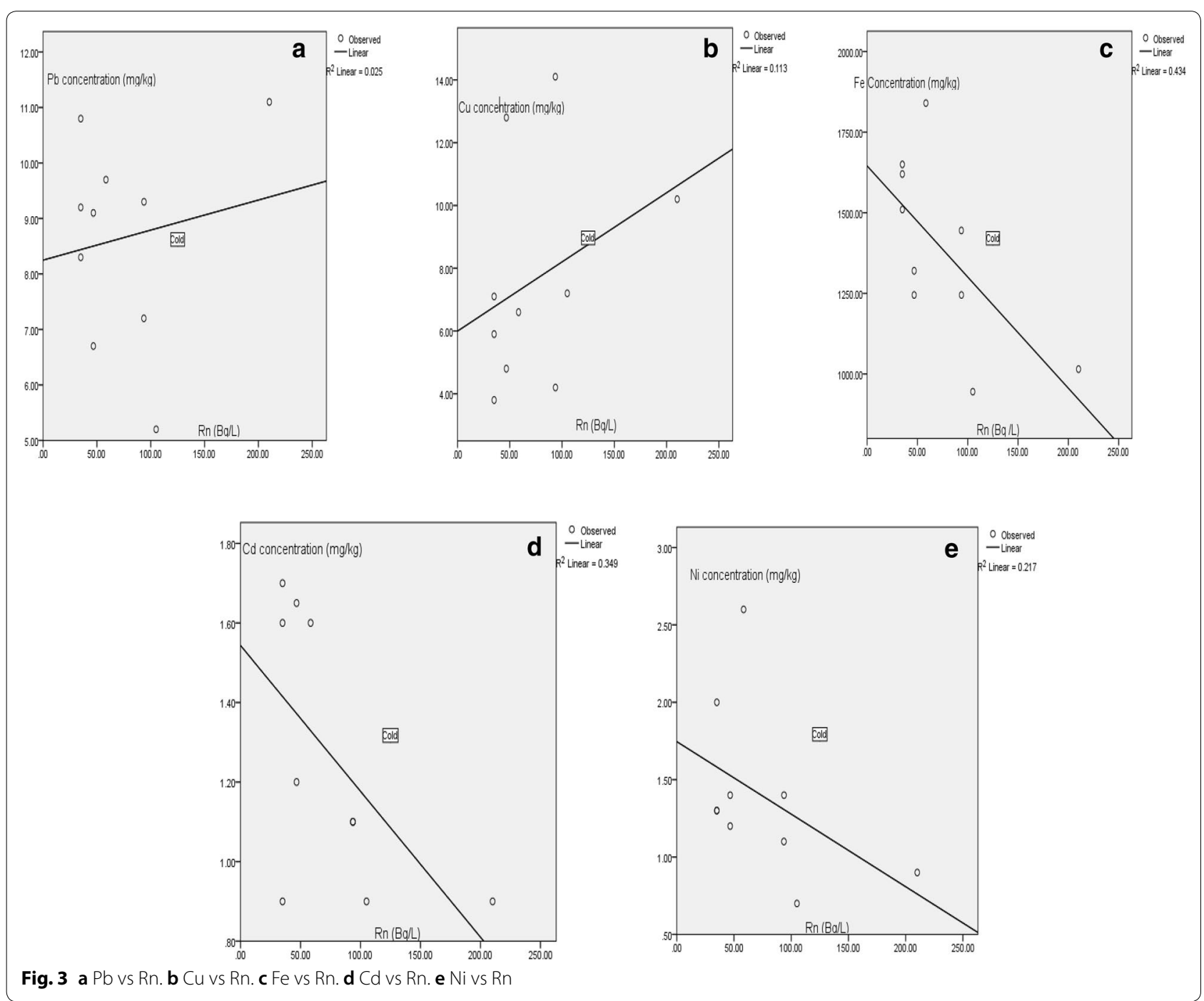


Faweya et al. Environ Syst Res (2018) 7:22

Page 14 of 17

$\mathrm{pH})$. The $\mathrm{pH}$ values correlated with $\mathrm{Pb}, \mathrm{Cu}, \mathrm{Fe}, \mathrm{Cd}$ and $\mathrm{Ni}$ showed no significant value in both cold and warm springs, an indication that the studied metals are immobile (Hamzeh et al. 2011). Both radon and heavy-metals are pollutants, Fig. 3a-e (Fig. $3 \mathrm{a} \mathrm{Pb}$ vs $\mathrm{Rn}$ Fig. $3 \mathrm{~b} \mathrm{Cu}$ vs Rn Fig. Bc Fe vs Rn Fig. Bd Cd vs Rn Fig. Be Ni vs Rn) and Fig. 4a-e (Fig. $4 \mathrm{a} \mathrm{Pb}$ vs Rn Fig. $4 \mathrm{~b} \mathrm{Cu}$ vs Rn Fig. Ac Fe vs Rn Fig. Ad Cd vs Rn Fig. Ae Cu vs $\mathrm{Rn}$ ) revealed the relationship between radon concentration and heavymetals. The results indicated moderate positive correlaton between Fe and Rn (Cold), Cd, Rn (cold), Cd and Rn (warm) and $\mathrm{Ni}$ and $\mathrm{Rn}$ (warm). Radon has poor negative correlations with all other elements which indicate differint geochemical behaviour.
Conclusions

The results of the average radon concentration in botteed, cold and warm spring's water samples in Ikogosi area were within the reference range recommended by the USEPA and UNSCEAR. The water in the studied area is safe for the members of the public irrespective of age brackets. The variation in the radon concentration may be due to geological structure of the area. The effecfive dose due to inhalation and ingestion was found to be within the safe limit $\left(100 \mu \mathrm{Sv}\right.$ year $\left.{ }^{-1}\right)$ recommended by $\mathrm{WHO}$ and EU. Dose due to inhalation of radon is higher as compared to ingestion. The mean concenration of metals increased according to this sequence $\mathrm{Ni}<\mathrm{Cd}<\mathrm{Cu}<\mathrm{Pb}<\mathrm{Fe}$. The result obtained by the sedimont quality guidelines classification revealed that most
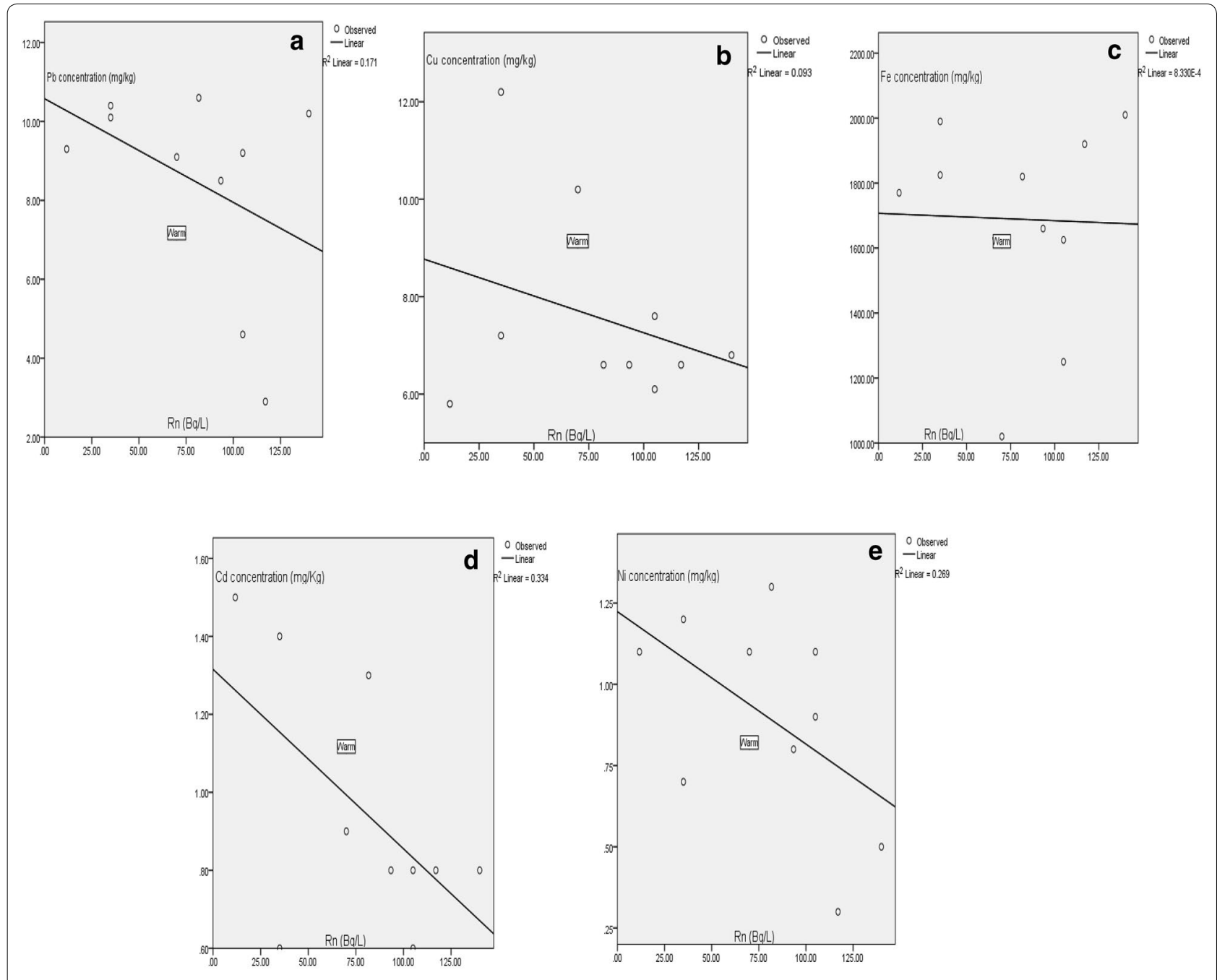

Fig. 4 a Pb vs Rn. b Cu vs Rn. c Fe vs Rn. d Cd vs Rn. e Cu vs Rn 
of the studied metals showed no negative biological effects such as reduced mental and central nervous function. Geoaccumulation index showed that all the samples are unpolluted with $\mathrm{Pb}, \mathrm{Cu}, \mathrm{Fe}$ and $\mathrm{Ni}$, while the values of $\mathrm{Cd}$ demonstrated to have none to moderate contamination. The EF values of $\mathrm{Cu}$ and $\mathrm{Ni}$ were below 1 in $90 \%$ of the sampling points, indicating that these metals in the sediments of all sampling points were derived mainly from natural processes. EF values of $\mathrm{Cd}$ were enriched in the bottom sediments by anthropogenic activities. Analysis of $\mathrm{QoC}$ shows that $\mathrm{Pb}, \mathrm{Cu}, \mathrm{Fe}$ and $\mathrm{Ni}$ demonstrated a geogenic source with no evidence of anthropogenic impacts, while the values of $\mathrm{Cd}$ revealed anthropogenic source. The high values of $\mathrm{Cd}$ identified might be related to human activities such as wastes (Islam et al. 2017) from tourists' visitation, materials deposition from those that seek for healings and sacrificial materials by the two spring's worshippers. Similar results were also found for the analysis of contamination factor $C_{f}^{i}$. Contamination factor $C_{f}^{i}$ demonstrated low contamination for all the studied metals except $\mathrm{Cd}$. Contamination factor values for $\mathrm{Cd}$ were mostly evaluated to have moderate contamination to considerable contamination. The values of PLI, determining the overall metal pollution in sediments (Zarei et al. 2014), showed no pollution status in all the studied points. Therefore, no health hazard is envisaged when water and sediment samples from the two springs are used for various purposes.

\section{Additional file}

Additional file 1: Figure S1. The readings obtained from countings. Figure S2. Typical alpha energy spectrum obtained.

\section{Abbreviations \\ AAS: atomic absorption spectrophotometer; APHA: American Public Health Association; AWWA: America Water Works Association; Ci-n: cold; ICRP: International Commission on Radiological Protection; EU: European Union; UAC: United Africa Company; USEPA: United States Environmental Protec- tion Agency; UNSCEAR: United Nations Scientific Committee on the Effects of Atomic Radiation; Wi-n: warm; WEF: water environment federation; WHO: World Health Organization; ND: not detectable.}

\section{Authors' contributions}

EBF conceived designed and wrote the paper, OGO went for the samplings, HTA did the graphic and TAA conducted the data analysis. All authors read and approved the final manuscript.

\section{Author details}

1 Radiation and Health Physics Division, Department of Physics, Faculty of Science, Ekiti State University, P.M.B 5363, Ado-Ekiti, Nigeria. ${ }^{2}$ Department of Physics, Faculty of Science, Ekiti State University, Ado-Ekiti, Nigeria. ${ }^{3}$ Department of Physics, Faculty of Science, Federal University, Lafia, Nigeria.

\section{Acknowledgements}

The authors appreciate the following people for samplings collection and laboratory analysis: they are Prof. Oni M.O, Mr. Yinka Ajiboye, Mr. Peter Elebonu, Mr. Jimoh Akeem and Mr. Adebayo Ayodeji.

\section{Competing interests}

The authors declare that they have no competing interests.

Availability of data and materials

The data are presented in the main manuscript.

Consent for publication

Not applicable.

Ethics approval and consent to participate

Not applicable.

\section{Funding}

The research was funded by all the authors.

\section{Publisher's Note}

Springer Nature remains neutral with regard to jurisdictional claims in published maps and institutional affiliations.

Received: 11 July 2018 Accepted: 25 August 2018

Published online: 15 September 2018

\section{References}

Alan MN, Chowdhury MI, Kamal M, Ghose S, Banu Hand-Chakrabarjy D (1997) Study of natural radionuclide concentrations in an area of elevated radiation background in the northern Districts of Bangladesh. Appl Radiat Isot 48:61-65

American Public Health Association (APHA) (1995) Standard methods of estimation of water and wastewater, 19th edn. America Water Works Association, Water Environment Federation, Washington

APHA, AWWA, WEF (1998) In: Clesceri LS, Greenberg AE, Eaton AD (eds) Standard methods for the examination of water and wastewater, 20th edn. American Water Work Association, Water Environment Federation, Washington D.C, pp 1-541

Asaah VA, Abimbola AF, Suh CE (2006) Heavy metal concentrations and distribution in Surface soils of the Bassa industrial Zone 1, Douala, Cameroun. Arab J Sci Eng 31(2):147-151

Banerjee U, Gupta S (2012) Source and distribution of lead, cadmium, iron and manganese in the river Damodar near Asansol Industrial Area, West Bengal, India. Int J Environ Sci 2:1531-1542

Bourai AA, Gusain GS, Rautela BS, Joshi V, Prasad G, Ramola RG (2012) Variations in radon concentration in groundwater of Kumaon Himalaya, India. Radiat Prot Dosimetry. https://doi.org/10.1093/rpd/ncs186

Calmano W, Wolfgang A, Forstner U (1990) Exchange of heavy metals between sediment components and water. In: Broekaert JAC, Gucer S, Adams $F$ (eds) Metal speciation in the environment. NATO ASI ser, ser G 23. Springer, Berlin, p 503

Cevik F, Ziya MLG, Derici OB, Findik O (2009) An assessment of metal pollution in surface sediments of Seyhandam by using enrichment factor, geoaccumulation index and statistical analyses. Environ Monit Assess 152:309-317

Chandrashekara MS, Veda SM, Paramesh L (2012) Studies on radiation dose due to radioactive elements present in ground water and soil samples around Mysore city, India. Radiat Prot Dosimetry 149(3):315-320. https:// doi.org/10.1093/rpd/ncr231

Choubey VM, Ramola RC (1997) Correlation between geology and radon levels in groundwater, soil and indoor air in Bhilangana valley, Garhwal Himalaya, India. Environ Geol 32:258-262

Choubey VM, Sharma KK, Ramol RC (1997) Geology of radon occurrence around Jari in Parvati valley, Himachal Pradesh, India. J Environ Radioact 34:139-147

Crawford-Brown DJ (1991) Risk and uncertainty analysis for radon in drinking water final report. American Water Works Association, Chapel Hill

De Martino S, Sabbrase C, Monetti G (1998) Radon emanation and exhalation rates from soils measured with an electrostatic collector. Appl Radiat Isot 49(4):407-413 
Ebrahimpour M, Mushrifah I (2008) Heavy metal concentration in water and sediments in Tasik chini, a freshwater lake, Malaysia. Environ Monit Assess 14(1-3):297-307

Edsfeldt C (2001) The radium distribution in some Swedish soils and its effect on radon emanation. Royal Institute of Technology, Stockholm, p 52

El-Taher A (2012) Measurement of radon concentrations and their annual effective dose exposure in groundwater from Qassim area, Saudi Arabia. J Environ Sci Technol 5:475-481. https://doi.org/10.3923/jest.2912-475.481

European Commission (2001) Commission recommendation of 20th December 2001 on the protection of the public against exposure to radon in drinking water. 2001/1982/Euratom.L344/85. Off J Eur Comm

Faweya EB (2007) Radiological implication of the natural radioactivity contents of sediments of rivers and streams in the Northern part of Ibadan city. Jurnal Fizik Malaysia 28(1\&2):17-21

Faweya EB, Babalola Al (2010) Radiological safety assessment and occurrence of heavy metals in soil from designated waste dumpsites used for building and composting in Southwestern Nigeria. Arab J Sci Eng 35(2A):219-225

Faweya EB, Farai IP (2006) Natural radioactivity content of the sediment of rivers and streams in the Northern part of Ibadan city. J Appl Environ Sci 2(29):142-146

Faweya EB, Oniya EO, Ojo FO (2013) Assessment of radiological parameters and heavy metal contents of sediment samples from lower Niger River, Nigeria. Arab J Sci Eng 38:1903-1908

Ghrefat HA, Yusuf N (2006) Assessing Mn, Fe, Cu, Zn, and Cd pollution in bottom Sediments of Wadi Al-Arab Dam, Jordan. Chemosphere 65:2114-2121

Ghrefat HA, Yousef A, Marc AR (2011) Application of geoaccumulation index and enriched factor for assessing metal contamination in the Sediments of Kafrain Dam, Jordan. Environ Monit Assess 178:95-109

Greeman V, Rose AW (1996) Factors controlling the emanation of radon and thoron in soils of the eastern USA. Chem Geol 129:1-14

Gundersen LCS, Schumann RR, Otton JK, Owen DE, Dubiel RF, Dickinson KA (1992) Geology of radon in United States. Geol Soc Am Spec Pap 271:1

Hairul NBI, Ojo KA, Kasimu MA, Gafar OY, Okoloba V, Mohammed SA (2013) Ikogosi warm water resorts: what you don't know? Interdiscip J Contemp Res Bus 4(9):280-303

Hakanson L (1980) An ecological risk index for aquatic pollution control. A sedimentological approach. Water Res 14(8):975-1001

Hamzeh MA, Aftabi A, Mirzaee M (2011) Assessing geochemical influence of traffic and other vehicle-related activities on heavy metal contamination in urban soils of Kerman city using a GIS-based approach. Environ Geochem Health 33(6):577-594

Hem JD (1985) Study and interpretation of chemical characteristics of natural water, 3rd edn. U.S. Geological Survey, Washington D.C

Hector A, Tatiana C, Jesus GR, Jonay G, del Maria CC, Miguel AA, Alicia T, Alejandro R, Francisco JP, Pablo M (2015) Radon in groundwater of the Northeastern Gran Canaria Aquifer. Water 7(2):575-2590. https://doi. org/10.3390/w7062575

IAEA (2013) Measurement and calculation of radon releases from Norm residues. TRS 474 (Technical Report Series 474). IAEA, Vienna

International Commission on Radiological Protection (ICRP) (2012) A compendium of dose coefficients base on ICRP Publication 60. ICRP, Publication 119. Oxford. Ann. ICRP 41(Suppl.)

Islam MS, Ahmed MK, Raknuzzaman M, Habibullah-Al-Mamun M, Islam MK (2015) Heavy metal pollution in surface water and sediment: a preliminary assessment of an urban river in a developing country. Ecol Ind 48:282-291

Islam MS, Habibullah-Al-Mamun M, Feng Y, Tokumura M, Masunaga S (2017) Chemical speciation of trace metals in the industrial sludge of Dhaka city, Bangladesh. Water Sci Technol 76:256-267

Jarup L (2003) Hazards of heavy metal concentrations. Br Bull 68:167-182

Karadede H, Unlu E (2000) Concentrations of some metals in water, sediment and fish species from the Ataturk Dam Lake (Euphrates), Turkey. Chemosphere 41:1371-1376

Kendall GM, Smith TJ (2002) Dose to organs and tissues from radon and its decay products. J Radiol Prot 22:389-406

Khuzestani RB, Souri B (2013) Evaluation of heavy metal contamination hazards in nuisance dust particles in Kurdistan Province, Western Iran. J Environ Sci 25(7):1346-1354
Kukoyi IA, Tijani NO, Adedara MT (2013) Evaluation of Ikogosi warm spring: a potential Geotourist site in Ekiti State, Southwest, Nigeria. Eur J Hosp Tour Res 1(3):1-9

Kumar A, Kaur M, Mehra R, Kumar DK, Mishra R (2017a) Comparative study of radon concentration with two techniques and elemental analysis in drinking water samples of the Jamiu district, Jamiu and Kashmir, India. Health Phys 113(4):1-9

Kumar A, Kaur M, Sharma S, Mehra R (2017b) A study of radon concentration in drinking water samples of Amritsar city of Punjab (India). Radiat Prot Environ 39:13-19

Lai WL, Chen JJ, Chung CY, Lee CG, Liao SW (2010) The influence of lagoon on neighboring rivers by water and sediment quality. Water Sci Technol 61(10):2477-2489

Liao SW, Sheu JY, Chen JJ, Lee GG (2006) Water quality assessment and apportionment source of pollution from Neighborings Rivers in Tapeng Laggon (Taiwan) using multivariate analysis: a case study. Water Sci Technol 54(11-12):47-55

Manzoor F, Alaamer AS, Tahir SNA (2008) Exposure to ${ }^{222} \mathrm{Rn}$ from consumption of underground municipal water supplies in Pakistan. Radiat Prot Dosimetry 130:392-396

Marazio-tis EA (1996) Effects of intraparticle porosity on the radon emanation coefficient. Environ Sci Technol 30:2441-2448

Martin GD, Vijay TG, Laluraj CM, Madhu NV, Joseph T, Nair M, Gupla GV, Balachandran KK (2010) Fresh water influence on nutrient stoichiometry in a tropical estuary, Southwest coast of India. Appl Ecol Environ Res 6(1):57-64

Momodu MA, Anyakora CA (2010) Heavy metal contamination of ground water: the Surulere case study. Res J Environ Earth Sci 2:39-43

Morillo J, Usero J, Gracia I (2004) Heavy metal distribution in marine sediments from the southwest coast of Spain. Chemosphere 55:431-442

Mose DG, Mushrush GW, Chrosniak C (1990) Indoor radon and well water radon in Virginia and Maryland. Arch Environ Cotam Toxicol 19(6):952-956

Muller G (1969) Index of geoaccumulation in sediments of the Rhine River. GeoJournal 2(3):108-118

Ojo JS, Olorunfemi MO, Falebita DE (2011) An appraisal of the geologic structure beneath the Ikogosi warm spring in south western Nigeria. J Appl Sci 5(1):75-79

Oladipo AA, Oluyemi EA, Tubosun IA, Fasasi MK, Ibitoye FI (2005) Chemical examination of Ikogosi warm spring in south western Nigeria. J Appl Sci 5(1):75-79

Oni MO, Oladapo OO, Amuda DB, Oni EA, Olive-Adelodun AO, Adewale KY, Fasina MO (2014) Radon concentration in groundwater of areas of high background radiation level in southwestern Nigeria. Niger J Phys 25(1):64-67

Oni EA, Oni OM, Oladapo OO, Olatunde ID, Adediwura FE (2016) Measurement of radon concentration in drinking water of Ado-Ekiti, Nigeria. J Acad Ind Res 4(8):190-192

Orkun ID, Galip S, Cagatayhan BE, Turan Y, Bulent S (2011) Assessment of metal pollution in water and surface sediments of the Seyhan River, Turkey, using different indexes. Clean Soil Air Water 39(2):185-194

Ortega L, Manzano M, Custodio E, Hornero J, Rodriguez-Arevalo J (2015) Using ${ }^{222} \mathrm{Rn}$ to identify and quantify groundwater inflow to the Mundo River (SE Spain). Chem Geol 395:67-79

Pravin US, Ansari MVA, Dixit NN (2014) Assessment of physic-chemical properties of sediments collected along the Mahul creek near Mumbai, India. Int Lett Nat Sci 16:54-61. https://doi.org/10.18052/www.scipress.com/ ILNS.16.54

Rasheed M (2010) Monitoring of contaminated toxic and heavy metals, from mine tailings through age accumulation, in soil and some wild plants in Southeast Egypt. J Hazard Mater 178:739-746

Ravikumar P, Somashekar RK (2014) Determination of the radiation dose dues to radon ingestion and inhalation. Int J Environ Sci Technol 11:493-508

Rogers AS, Imevbore AMA, Adegoke OS (1969) Physical and chemical properties of Ikogosi warm springs, Western Nigeria. J Min Geol 4:69-81

Schubert M, Brueggemman L, Knoeller K, Schirmer M (2011) Using radon as an environmental tracer for estimating groundwater flow velocities in single well tests. Water Resour Res. https://doi.org/10.1029/2010Wr009572

Sharon B, Montepelier VT (1997) Testing the waters: chemical and physical vital signs of a river: river watch network. ISBN: 0787234923. www.fosc.org/ WOData/WOparameter.htm 
Shuanxi F (2014) Assessment of heavy metal pollution in stream sediments for the Baoji city section of the Welhe River in Northwest China. Water Sci Technol 70(7):1279-1284. https://doi.org/10.2166/wst.2014.366

Skeppstrom K, Olofsson B (2007) Uranium and radon in groundwater. Eur Water 17:51-62

Song D, Zhuang D, Jiang D, Fu J, Wang Q (2015) Integrated health risk assessment of heavy metals in Suxian County, South China. Int J Environ Res Public Health 12:7100-7117

Stephen DM, Mohammad RS, Eric W, Sabine A, Roberto C (2004) An assessment of metal contamination in coastal sediments of the Caspian sea. Mar Pollut Bull 48:61-77

Stringer C, Burnett WC (2004) Sample bottle design improvements for radon emanation analysis of natural waters. Health Phys 87:642-646

Tomlinson D, Wilson J, Harris C, Jeffrey DD (1980) Problems in the assessment of heavy metal levels in estuaries and the formation of a pollution index. Helgolander Meeresuntersuchunger 33(1-4):566-575

Toscani L, Martinell G, Dalledonne C (2001) Proceedings 5th international conference on rare gas geochemistry, (EDS), Debrecen, Hungary, p 321

Tukura BW, Ayinya MIG, Ibrahim IG, Onche EU (2014) Assessment of heavy metals in groundwater from Nasarawa State, Middle Belt, and Nigeria. Am Chem Sci J 4:798-812

Turekian KK, Wedepohl KH (1961) Distribution of the elements in some major units of the earth's crust. Geol Soc Am Bull 72(2):175-192

United States Environmental Protection Agency (USEPA) (1991) Federal register 40 parts 141 and 142: national primary drinking water regulations; radionuclides: proposed rule. U.S. Government Printing Office, Washing ton, D.C; Federal Register 64:9559-9599
United States Environmental Protection Agency (USEPA) (1999) Radon in drinking water health risk reduction and cost analysis. USEPA, office of Radiation Programs, Washington, D.C; USEPA Federal Register 64

United Nations Scientific Committee on the Effects of Atomic Radiation (UNSCEAR) (2000) Sources and effects of ionizing radiation. In: Report to the general assembly with scientific annexes. United Nations, New York

World Health Organization (WHO) (2004) Guidelines for drinking water quality, vol 1. World Health Organization, Geneva

World Health Organization (WHO) (2011) Guidelines for drinking water quality. In: Radiological aspects. World Health Organization, Geneva, pp 214-217

Xinwei $L$ (2006) Analysis of radon concentration in drinking water in Baoji China and the associated health effects. Radiat Prot Dosimetry 121(4):452-455

Yogesh PG, Choubry P, Ramola VC (2009) Geohydrological control on radon availability in groundwater. Radiat Meas 44(1):122-126

Yu D, Kim KJA (2004) A physiologically based assessment of human exposure to radon released from groundwater. Chemosphere 54:639-645

Zarei I, Pourkhabbaz A, Khuzestani RB (2014) An assessment of metal contaminant risk in sediments of Hara Biosphere Reserve Southern Iran with a focus on application of pollution indicators. Environ Monit Assess. https:// doi.org/10.1007/s10661-014-3439-X

Zhang W, Feng H, Chang J, Qu J, Xie H, Yu L (2009) Heavy metal contamination in surface sediments of Yangtze River Intertidal Zone: an assessment from different indexes. Environ Pollut 157:1533-1543

Zhang C, Qiao Q, Piper JDA, Huang B (2011) Assessment of heavy metal from a Fe-smelting plant in urban river sediments using environmental magnetic and geochemical methods. Environ Pollut 159:3057-3070

\section{Submit your manuscript to a SpringerOpen ${ }^{\circ}$ journal and benefit from:}

- Convenient online submission

- Rigorous peer review

- Open access: articles freely available online

- High visibility within the field

- Retaining the copyright to your article

Submit your next manuscript at $\boldsymbol{\nabla}$ springeropen.com 